\title{
Comparative proteomic analysis provides novel insight into the interaction between resistant vs susceptible tomato cultivars and TYLCV infection
}

\author{
Ying Huang ${ }^{1}$, Hong-Yu Ma², Wei Huang ${ }^{1}$, Feng Wang ${ }^{1}$, Zhi-Sheng $\mathrm{Xu}^{1}$ and Ai-Sheng Xiong ${ }^{1 *}$
}

\begin{abstract}
Background: Tomato yellow leaf curl virus (TYLCV) is a member of the family Geminiviridae, genus Begomovirus. The virus is a widespread plant virus that causes important economic losses in tomatoes. Genetic engineering strategies have increasingly been adopted to improve the resistance of tomatoes to TYLCV.

Results: In this study, a proteomic approach was used to investigate the molecular mechanisms involved in tomato leaf defense against TYLCV infection. Proteins extracted from leaves of resistant tomato cultivar 'Zheza-301' and susceptible cultivar 'Jinpeng-1' after TYLCV infection were analyzed using two-dimensional gel electrophoresis. Eighty-six differentially expressed proteins were identified and classified into seven groups based on their functions. For several of the proteins, including $\mathrm{CDC} 48, \mathrm{CHI}$ and $\mathrm{HSC70}$, expression patterns measured using quantitative real-time PCR differed from the results of the proteomic analysis. A putative interaction network between tomato leaves and TYLCV infection provides us with important information about the cellular activities that are involved in the response to TYLCV infection.

Conclusions: We conducted a comparative proteomic study of TYLCV infection in resistant and susceptible tomato cultivars. The proteins identified in our work show a variety of functions and expression patterns in the process of tomato-TYLCV interaction, and these results contribute to our understanding of the mechanism underlying TYLCV resistance in tomatoes at the protein level.
\end{abstract}

Keywords: TYLCV, Proteomic approach, 2-DE, Expression pattern, Tomato

\section{Background}

Tomato yellow leaf curl virus (TYLCV), is a member of the genus Begomovirus of the family Geminiviridae, which has three other genera, namely, Mastrevirus, Curtovirus and Topocuvirus, and contains a circular single-stranded DNA (ssDNA) molecule $2.7-2.8 \mathrm{~kb}$ in length $[1,2]$. The TYLCV genome encodes six open reading frames (ORFs): two overlapping ORFs AV1 (encoding capsid protein), AV2 (encoding movement protein MP), and ORFs AC1-AC4 (encoding replication-associated protein Rep, transcriptional activator $\operatorname{TrA}$, replication enhancer protein REn and

\footnotetext{
* Correspondence: xiongaisheng@njau.edu.cn

${ }^{1}$ State Key Laboratory of Crop Genetics and Germplasm Enhancement, College of Horticulture, Nanjing Agricultural University, 1 Weigang, Nanjing 210095, Jiangsu, China

Full list of author information is available at the end of the article
}

induction of plant cell division protein, respectively) on the complementary-sense strand [3-8]. TYLCV, which is transmitted by the whitefly Bemisia tabaci, threatens up to 20 different plant species, including pumpkin, tobacco and tomato $[9,10]$. TYLCV infection begins when the viruliferous whitefly B. tabaci feeds by inserting its proboscis into leaves, transmitting the virus to the host cells of the plant [11]. Upon entering the host cell, the ssDNA genome of TYLCV begins replicating through a rolling circle mechanism. TYLCV can spread to adjacent cells via the complex cytoplasm and plasmodesmata, inducing a new infection process.

After about 2 weeks of TYLCV infection, symptoms become increasingly apparent, with yellow and shriveled leaves, dwarfed plants, withered flowers and growth 
retardation, causing serious economic loss. Increasing numbers of genes involved in the response to TYLCV infection have been identified, such as GroEL [12], a developmentally regulated lipocalin-like gene SlVRSLip [13], and transcription factors, including bHLH [14], AP2/ERF [15], NAC [16]. Comparative transcriptomics and metabolomics have also been conducted in resistant and susceptible tomato cultivars to analyze the mechanisms of resistance to TYLCV infection [16, 17].

In recent years, several strategies have demonstrated the advantages of the proteomics approach for studying underlying plant physiological processes, such as plant defense response. A proteomic analysis of root proteins in avocado infected with Phytophthora cinnamomi identified 21 differentially expressed proteins, including homologs to glutathione S-transferase, isoflavone reductase and several abscisic acid stressripening proteins [18]. Moreover, a study of interaction with Lasiodiplodia theobromae infection in cashew plants identified 73 proteins with significantly different expression levels, which were mainly involved in energy metabolism pathways, stress and defense, protein metabolism and cell signaling [19].

Whitefly-transmitted geminiviruses such as the begomovirus TYLCV pose a serious threat to tomato production. Breeding of tomatoes resistant to TYLCV started in the late 1960s [20]. Tomato genotypes with resistance to begomoviruses are derived from different wild species. To date, five loci linked to resistance have been identified: $\mathrm{Ty}-1 / \mathrm{Ty}-3$ and $\mathrm{Ty}-4$ from $S$. chilense, $\mathrm{Ty}-2$ from $S$. habrochaites and Ty-5 from S. peruvianum [17]. And two genes associated with these Ty loci, Ty- $1 / \mathrm{Ty}-3$ and Ty-5, have been identified $[21,22]$. To investigate the tomato-TYLCV interaction, we conducted a proteomic analysis in resistant and susceptible tomato cultivars after TYLCV infection. Leaf proteins of resistant tomato cultivar 'Zheza-301' and susceptible cultivar 'Jinpeng-1' were extracted at 19 days post infection (dpi) and analyzed using two-dimensional gel electrophoresis (2-DE). Eighty-six proteins were identified and classified into different functional categories. The expression levels of 19 genes encoding these proteins were analyzed at six time points after infection $(2,4,6,10,15$ and $19 \mathrm{dpi})$ by quantitative real-time PCR (qRT-PCR). A putative TYLCV infection response network in tomato leaves was constructed.

This work mainly (1) identified proteins significantly expressed in response to TYLCV infection in tomatoes; (2) analyzed the proteins that were differentially expressed between resistant and susceptible tomato cultivars; (3) revealed the defense mechanism between tomato and TYLCV in proteins and biochemical process level; and (4) analyzed the interaction network in the cells of tomato leaves after TYLCV infection. The overall results contribute significantly to our understanding of protein response and alteration and provide insights into the molecular mechanisms involved in response to TYLCV infection in tomatoes.

\section{Results}

Symptoms of resistant and susceptible tomato cultivars in response to TYLCV infection

Two leaf-stage tomato cultivars (resistant variety: 'Zheza301', susceptible variety: 'Jinpeng-1') were exposed to viruliferous whiteflies. The two tomato cultivars showed no symptoms at $10 \mathrm{dpi}$. At $17 \mathrm{dpi}$, there was a little yellowing in the leaves of 'Jinpeng-1' (Additional file 1: Figure S1). Compared with the control plants, 'Jinpeng-1' samples presented a typical TYLCV phenotype, with curly yellow leaves at 19 dpi. In contrast, 'Zheza-301' exhibited no symptoms (Fig. 1). For better comparative understanding of the development of TYLCV infection, the leaves of the two tomato cultivars at $19 \mathrm{dpi}$ and control plants were collected and frozen in liquid nitrogen to extract protein and total genomic DNA. To detect TYLCV accumulation, semi-quantitative PCR was conducted using the primers TYLCV-01 (Additional file 2: Table S1). As shown in Fig. 2, in control plants, there was no TYLCV accumulation in either 'Zheza-301' or 'Jinpeng-1' at different PCR cycles. In TYLCV infected plants, after 23 PCR cycles, there was high expression of TYLCV DNA in 'Jinpeng-1', while there was weak or no expression in 'Zheza-301'. TYLCV DNA was clearly present in 'Zheza-301' after about 25 cycles, but at lower levels than in 'Jinpeng-1'.

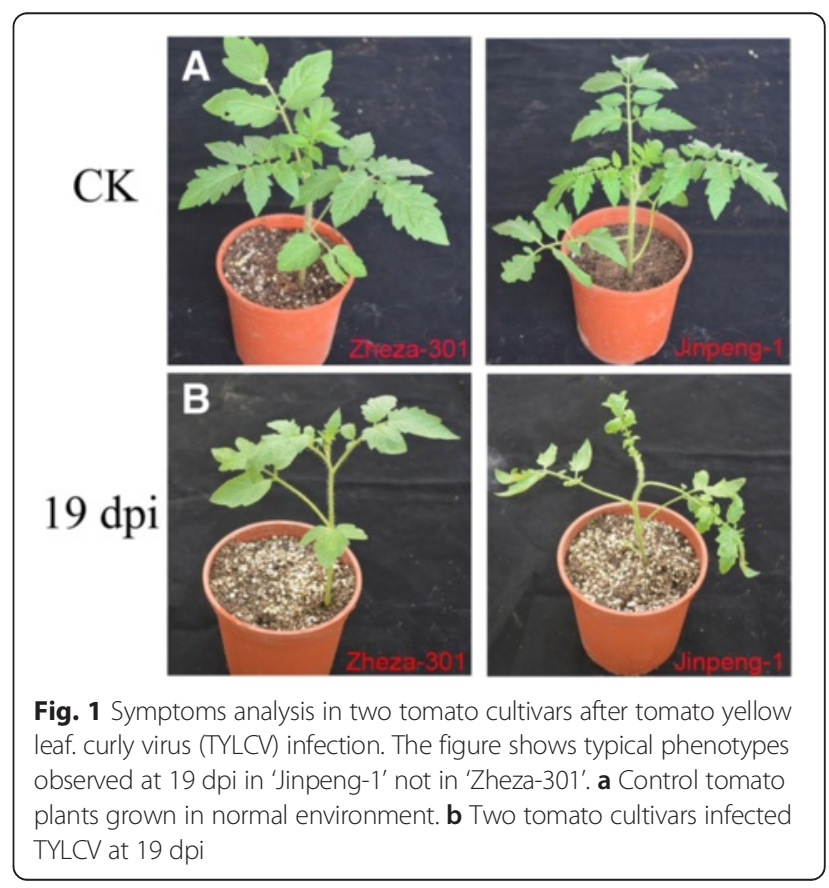




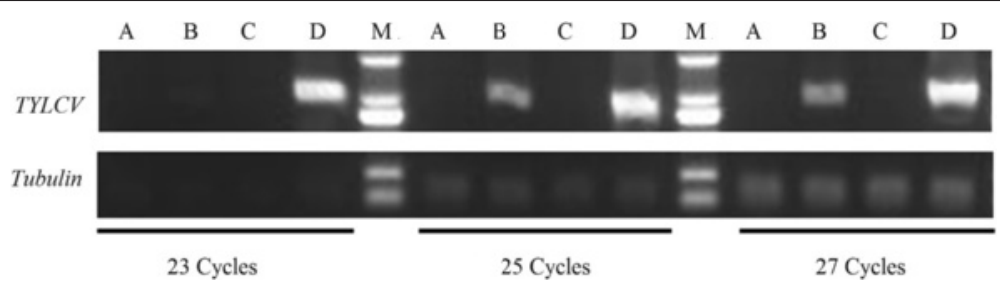

Fig. 2 Detection of the accumulation of TYLCV CP in two tomato cultivars by semi-quantitative PCR at different PCR cycles. A: Control plant: Zheza-301. B: Treatment plant: Zheza-301 after TYLCV infection at 19 dpi. C: Control plant: Jinpeng-1. D: Treatment plant: Jinpeng-1 after TYLCV infection at 19 dpi. M: Marker

\section{2-DE analysis of tomato leaf proteins after TYLCV infection}

As described above, samples for protein extraction were collected at $19 \mathrm{dpi}$, when the leaves of susceptible cultivar 'Jinpeng-1'were yellow and curly. Total proteins of the two tomato cultivars ('Zheza-301': control and TYLCV infection; 'Jinpeng-1': control and TYLCV infection) were separated using 2-DE. Representative maps of three biological replicates are shown in Additional file 3: Figure S2.

Over 500 protein spots were detected in each gel with different expression abundance. To detect differentially expressed proteins, the protein abundance ratios $\mathrm{Z}_{\mathrm{T}} / \mathrm{Z}_{\mathrm{C}}$ (treatment /control plants of 'Zheza-301') and $\mathrm{J}_{\mathrm{T}} / \mathrm{J}_{\mathrm{C}}$ (treatment/control plants of 'Jinpeng-1') were calculated for each spot. $\mathrm{Z}_{\mathrm{C}} / \mathrm{J}_{\mathrm{C}}$ and $\mathrm{Z}_{\mathrm{T}} / \mathrm{J}_{\mathrm{T}}$ were also calculated to analyze differences between the two tomato cultivars. A total of 86 spots with apparent molecular mass between 26.08 and $114.02 \mathrm{kDa}$ and isoelectric point $(p I)$ between
4.69 and 8.96 showed significantly differential expression with more than 2.0 -fold or less than 0.5 -fold differences in abundance ratios (Fig. 3). Identified proteins are shown in Table 1. Among the 86 protein spots, four spots (spot 34 , spot 35, spot 36 and spot 53) showed no significant difference in expression with infection but significant differences in expression between the two tomato cultivars. These proteins did not respond significantly to TYLCV infection at $19 \mathrm{dpi}$, but were related to differences between the two tomato cultivars. The significantly differentially expressed proteins in TYLCV infection in the two tomato cultivars are shown in Fig. 4.

\section{Functional classification of identified proteins involved in TYLCV infection}

All 86 differentially expressed proteins were successfully identified as plant proteins. As shown in Fig. 5a, the proteins were classified into the following functional classes according to the Kyoto Encyclopedia of

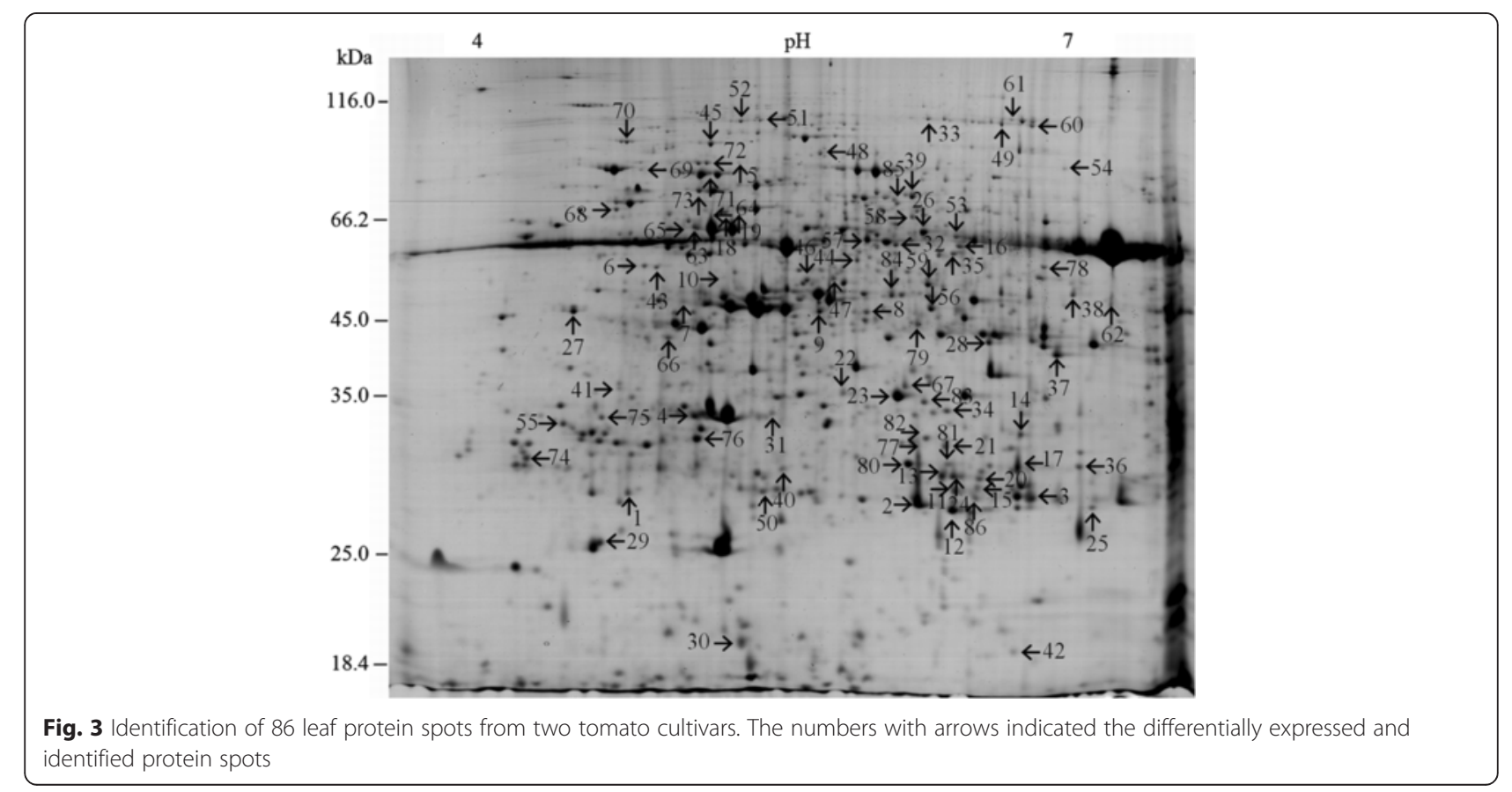


Table 1 A total of 86 differentially expressed proteins identified in resistant and susceptible tomato cultivars after TYLCV infection

\begin{tabular}{|c|c|c|c|c|c|c|c|c|c|c|}
\hline aspot no. & $\begin{array}{l}{ }^{\mathrm{b}} \text { Accession } \\
\text { no. }\end{array}$ & $\begin{array}{l}\text { 'Protein name, } \\
\text { Orgnaism }\end{array}$ & $\begin{array}{l}\text { dProtein } \\
\text { score }\end{array}$ & ${ }^{\mathrm{e} S C}$ & ${ }^{\mathrm{f}} \mathrm{MP}$ & $\begin{array}{l}{ }^{9} \mathrm{MW} \\
(\mathrm{kDa}) / \mathrm{pl}\end{array}$ & ${ }^{{ }^{2}} Z_{C} / J_{C}$ & ${ }^{h_{Z}} /_{T}$ & ${ }^{{ }^{n}} Z_{T} / Z_{C}$ & ${ }^{h} J_{T} / J_{C}$ \\
\hline \multicolumn{11}{|c|}{ Photosynthesis } \\
\hline 1 & gi|407970998 & $\begin{array}{l}\text { Chlorophyll a-b binding protein } 4, \\
\text { Solanum lycopersicum }\end{array}$ & 135 & 13 & 2 & $\begin{array}{l}28.98 / \\
5.33\end{array}$ & $\begin{array}{l}0.31^{*} \pm \\
0.15\end{array}$ & $\begin{array}{l}0.45^{*} \pm \\
0.35\end{array}$ & $\begin{array}{l}0.22^{*} \pm \\
0.13\end{array}$ & $\begin{array}{l}0.18^{*} \pm \\
0.09\end{array}$ \\
\hline 2 & gi|115813 & $\begin{array}{l}\text { Chlorophyll a-b binding protein } 8 \text {, } \\
\text { Solanum lycopersicum }\end{array}$ & 212 & 15 & 5 & $\begin{array}{l}29.34 / \\
8.96\end{array}$ & $\begin{array}{l}1.09 \pm \\
0.22\end{array}$ & $\begin{array}{l}0.45^{*} \pm \\
0.35\end{array}$ & $\begin{array}{l}0.25^{*} \pm \\
0.06\end{array}$ & $\begin{array}{l}0.90 \pm \\
0.33\end{array}$ \\
\hline 3 & gi|460405507 & $\begin{array}{l}\text { Chlorophyll a-b binding protein } 8 \text {, } \\
\text { Solanum lycopersicum }\end{array}$ & 81 & 4 & 1 & $\begin{array}{l}29.26 / \\
8.65\end{array}$ & $\begin{array}{l}1.34 \pm \\
0.25\end{array}$ & $\begin{array}{l}1.78 \pm \\
0.30\end{array}$ & $\begin{array}{l}0.46^{*} \pm \\
0.03\end{array}$ & $\begin{array}{l}0.36^{*} \pm \\
0.13\end{array}$ \\
\hline 4 & gi|460375240 & $\begin{array}{l}\text { Oxygen-evolving enhancer protein 1, } \\
\text { Solanum lycopersicum }\end{array}$ & 273 & 10 & 2 & $\begin{array}{l}35.15 / \\
5.91\end{array}$ & $\begin{array}{l}0.84 \pm \\
0.07\end{array}$ & $\begin{array}{l}0.18^{*} \pm \\
0.01\end{array}$ & $\begin{array}{l}0.31^{*} \pm \\
0.04\end{array}$ & $\begin{array}{l}1.49 \pm \\
0.38\end{array}$ \\
\hline 5 & gi|460372520 & $\begin{array}{l}\text { Oxygen-evolving enhancer protein } 1 \text {, } \\
\text { Solanum lycopersicum }\end{array}$ & 99 & 19 & 2 & $\begin{array}{l}35.48 / \\
5.84\end{array}$ & $\begin{array}{l}1.93 \pm \\
0.19\end{array}$ & $\begin{array}{l}0.18^{*} \pm \\
0.01\end{array}$ & $\begin{array}{l}2.21^{*} \pm \\
0.44\end{array}$ & $\begin{array}{l}10.57^{*} \pm \\
0.52\end{array}$ \\
\hline 6 & gi|460408969 & $\begin{array}{l}\text { Rubisco accumulation factor } 1, \\
\text { Solanum Iycopersicum }\end{array}$ & 119 & 9 & 3 & $\begin{array}{l}50.46 / \\
5.10\end{array}$ & $\begin{array}{l}5.36^{*} \pm \\
0.28\end{array}$ & $\begin{array}{l}1.85 \pm \\
0.28\end{array}$ & $\begin{array}{l}0.77 \pm \\
0,29\end{array}$ & $\begin{array}{l}2.18^{*} \pm \\
0.39\end{array}$ \\
\hline 7 & gi|460401823 & $\begin{array}{l}\text { Ribulose bisphosphate } \\
\text { carboxylase/oxygenase activase 1, } \\
\text { Solanum lycopersicum }\end{array}$ & 56 & 3 & 1 & $\begin{array}{l}49.05 / \\
8.15\end{array}$ & $\begin{array}{l}0.09^{*} \pm \\
0.04\end{array}$ & $\begin{array}{l}0.57 \pm \\
0.12\end{array}$ & $\begin{array}{l}6.75^{*} \pm \\
0.18\end{array}$ & $\begin{array}{l}1.07 \pm \\
0.29\end{array}$ \\
\hline 8 & gi|723739979 & $\begin{array}{l}\text { Ribulose bisphosphate } \\
\text { carboxylase/oxygenase activase, } \\
\text { Solanum lycopersicum }\end{array}$ & 285 & 11 & 3 & $\begin{array}{l}50.97 / \\
8.76\end{array}$ & $\begin{array}{l}0.88 \pm \\
0.20\end{array}$ & $\begin{array}{l}0.38^{*} \pm \\
0.30\end{array}$ & $\begin{array}{l}0.07^{*} \pm \\
0.05\end{array}$ & $\begin{array}{l}0.16^{*} \pm \\
0.01\end{array}$ \\
\hline 9 & gi|1778414 & $\begin{array}{l}\text { Ribulose 1,5-bisphosphate } \\
\text { carboxylase/oxygenase activase, } \\
\text { Oryza sativa }\end{array}$ & 126 & 7 & 2 & $\begin{array}{l}48.06 / \\
5.85\end{array}$ & $\begin{array}{l}0.39^{*} \pm \\
0.04\end{array}$ & $\begin{array}{l}0.78 \pm \\
0.16\end{array}$ & $\begin{array}{l}3.45^{*} \pm \\
0.40\end{array}$ & $\begin{array}{l}1.73 \pm \\
0.01\end{array}$ \\
\hline 10 & gi|100380 & $\begin{array}{l}\text { Ribulose bisphosphate carboxylase } \\
\text { activase, Nicotiana tabacum }\end{array}$ & 103 & 7 & 1 & $\begin{array}{l}26.08 / \\
5.01\end{array}$ & $\begin{array}{l}0.05^{*} \pm \\
0.01\end{array}$ & $\begin{array}{l}0.03^{*} \pm \\
0.02\end{array}$ & $\begin{array}{l}3.25^{*} \pm \\
0.44\end{array}$ & $\begin{array}{l}5.57^{*} \pm \\
0.43\end{array}$ \\
\hline 11 & gi|488453358 & $\begin{array}{l}\text { Ribulose 1,5-bisphosphate carboxylase, } \\
\text { Solanum lycopersicum }\end{array}$ & 171 & 6 & 3 & $\begin{array}{l}48.57 / \\
6.71\end{array}$ & $\begin{array}{l}1.22 \pm \\
0.14\end{array}$ & $\begin{array}{l}43.48^{*} \pm \\
0.38\end{array}$ & $\begin{array}{l}0.04^{*} \pm \\
0.01\end{array}$ & $\begin{array}{l}0.01^{*} \pm \\
0,01\end{array}$ \\
\hline 12 & gi|488453358 & $\begin{array}{l}\text { Ribulose 1,5-bisphosphate carboxylase, } \\
\text { Solanum lycopersicum }\end{array}$ & 313 & 13 & 5 & $\begin{array}{l}48.57 / \\
6.71\end{array}$ & $\begin{array}{l}1.58 \pm \\
0.11\end{array}$ & $\begin{array}{l}23.71^{*} \pm \\
0.28\end{array}$ & $\begin{array}{l}0.06^{*} \pm \\
0.01\end{array}$ & $\begin{array}{l}0.02^{*} \pm \\
0.01\end{array}$ \\
\hline 13 & gi|488453358 & $\begin{array}{l}\text { Ribulose 1,5-bisphosphate carboxylase, } \\
\text { Solanum lycopersicum }\end{array}$ & 62 & 4 & 2 & $\begin{array}{l}48.57 / \\
6.71\end{array}$ & $\begin{array}{l}1.37 \pm \\
0.22\end{array}$ & $\begin{array}{l}4.53^{*} \pm \\
0.25\end{array}$ & $\begin{array}{l}0.05^{*} \pm \\
0.01\end{array}$ & $\begin{array}{l}0.05^{*} \pm \\
0.01\end{array}$ \\
\hline 14 & gi|488453358 & $\begin{array}{l}\text { Ribulose 1,5-bisphosphate carboxylase, } \\
\text { Solanum lycopersicum }\end{array}$ & 124 & 8 & 3 & $\begin{array}{l}48.57 / \\
6.71\end{array}$ & $\begin{array}{l}0.83 \pm \\
0.15\end{array}$ & $\begin{array}{l}1.89 \pm \\
0.20\end{array}$ & $\begin{array}{l}0.09^{*} \pm \\
0.01\end{array}$ & $\begin{array}{l}0.04^{*} \pm \\
0.01\end{array}$ \\
\hline 15 & gi|1293000 & $\begin{array}{l}\text { Ribulose 1,5-bisphosphate } \\
\text { carboxylase/oxygenase large subunit, } \\
\text { Cheirodendron trigynum }\end{array}$ & 200 & 6 & 3 & $\begin{array}{l}52.90 / \\
6.31\end{array}$ & $\begin{array}{l}0.63 \pm \\
0.04\end{array}$ & $\begin{array}{l}1.18 \pm \\
0.20\end{array}$ & $\begin{array}{l}0.10^{*} \pm \\
0.05\end{array}$ & $\begin{array}{l}0.06^{*} \pm \\
0.01\end{array}$ \\
\hline 16 & gi|168282 & $\begin{array}{l}\text { Ribulose 1,5-bisphosphate } \\
\text { carboxylase/oxygenase large subunit, } \\
\text { Lactoris fernandeziana }\end{array}$ & 281 & 16 & 4 & $\begin{array}{l}44.16 / \\
6.33\end{array}$ & $\begin{array}{l}0.19^{*} \pm \\
0.02\end{array}$ & $\begin{array}{l}0.28^{*} \pm \\
0.02\end{array}$ & $\begin{array}{l}2.60^{*} \pm \\
0.39\end{array}$ & $\begin{array}{l}1.76 \pm \\
0.24\end{array}$ \\
\hline 17 & gi|21069067 & $\begin{array}{l}\text { Ribulose 1,5-bisphosphate } \\
\text { carboxylase/oxygenase large subunit, } \\
\text { Asplenium jahandiezii }\end{array}$ & 60 & 4 & 1 & $\begin{array}{l}39.38 / \\
7.31\end{array}$ & $\begin{array}{l}1.00 \pm \\
0.26\end{array}$ & $\begin{array}{l}0.29^{*} \pm \\
0.10\end{array}$ & $\begin{array}{l}0.02^{*} \pm \\
0.01\end{array}$ & $\begin{array}{l}0.09^{*} \pm \\
0.08\end{array}$ \\
\hline 18 & gi|460379814 & $\begin{array}{l}\text { RubisCO large subunit-binding protein } \\
\text { subunit beta, Solanum lycopersicum }\end{array}$ & 203 & 10 & 4 & $\begin{array}{l}64.53 / \\
5.46\end{array}$ & $\begin{array}{l}5.11^{*} \pm \\
0.34\end{array}$ & $\begin{array}{l}2.87^{*} \pm \\
0.15\end{array}$ & $\begin{array}{l}1.26 \pm \\
0.06\end{array}$ & $\begin{array}{l}2.24^{*} \pm \\
0.19\end{array}$ \\
\hline 19 & gi|460366131 & $\begin{array}{l}\text { RubisCO large subunit-binding protein } \\
\text { subunit beta, Solanum lycopersicum }\end{array}$ & 53 & 4 & 2 & $\begin{array}{l}63.24 / \\
5.72\end{array}$ & $\begin{array}{l}1.15 \pm \\
0.36\end{array}$ & $\begin{array}{l}2.81^{*} \pm \\
0.25\end{array}$ & $\begin{array}{l}0.69 \pm \\
0.08\end{array}$ & $\begin{array}{l}0.28^{*} \pm \\
0.09\end{array}$ \\
\hline 20 & gi|92087012 & $\begin{array}{l}\text { Ribulose bisphosphate carboxylase } \\
\text { large chain OS, Solanum lycopersicum }\end{array}$ & 65 & 6 & 3 & $\begin{array}{l}53.43 / \\
6.55\end{array}$ & $\begin{array}{l}0.77 \pm \\
0.12\end{array}$ & $\begin{array}{l}10.02^{*} \pm \\
0.24\end{array}$ & $\begin{array}{l}0.09^{*} \pm \\
0.01\end{array}$ & $\begin{array}{l}0.01^{*} \pm \\
0.01\end{array}$ \\
\hline 21 & gi|92087012 & $\begin{array}{l}\text { Ribulose bisphosphate carboxylase } \\
\text { large chain OS, Solanum lycopersicum }\end{array}$ & 121 & 14 & 6 & $\begin{array}{l}53.43 / \\
6.55\end{array}$ & $\begin{array}{l}1.18 \pm \\
0.07\end{array}$ & $\begin{array}{l}32.57^{*} \pm \\
0.19\end{array}$ & $\begin{array}{l}0.08^{*} \pm \\
0.01\end{array}$ & $\begin{array}{l}0.01^{*} \pm \\
0.01\end{array}$ \\
\hline 22 & gi|460375527 & $\begin{array}{l}\text { Ferredoxin-NADP reductase, leaf-type } \\
\text { isozyme, Solanum lycopersicum }\end{array}$ & 118 & 13 & 3 & $\begin{array}{l}40.90 / \\
8.67\end{array}$ & $\begin{array}{l}0.28^{*} \pm \\
0.07\end{array}$ & $\begin{array}{l}0.93 \pm \\
0.47\end{array}$ & $\begin{array}{l}0.42^{*} \pm \\
0.10\end{array}$ & $\begin{array}{l}0.14^{*} \pm \\
0.02\end{array}$ \\
\hline 23 & gi|460373374 & $\begin{array}{l}\text { FerredoxinvNADP reductase, leaf-type } \\
\text { isozyme, Solanum lycopersicum }\end{array}$ & 299 & 20 & 5 & $\begin{array}{l}40.77 / \\
8.37\end{array}$ & $\begin{array}{l}0.82 \pm \\
0.07\end{array}$ & $\begin{array}{l}0.61 \pm \\
0.07\end{array}$ & $\begin{array}{l}0.48^{*} \pm \\
0.02\end{array}$ & $\begin{array}{l}0.65 \pm \\
0.05\end{array}$ \\
\hline
\end{tabular}


Table 1 A total of 86 differentially expressed proteins identified in resistant and susceptible tomato cultivars after TYLCV infection (Continued)

\begin{tabular}{|c|c|c|c|c|c|c|c|c|c|c|}
\hline & & $\begin{array}{l}\text { Carbonic anhydrase, } \\
\text { Solanum lycopersicum }\end{array}$ & & & & $\begin{array}{l}34.85 / \\
6.67\end{array}$ & $\begin{array}{l}1.45 \pm \\
0.12\end{array}$ & $\begin{array}{l}3.21^{*} \pm \\
0.27\end{array}$ & $\begin{array}{l}0.85 \pm \\
0.12\end{array}$ & $\begin{array}{l}0.38^{*} \pm \\
0.05\end{array}$ \\
\hline 25 & gi|350537679 & $\begin{array}{l}\text { Carbonic anhydrase, } \\
\text { Solanum lycopersicum }\end{array}$ & 98 & 5 & 1 & $\begin{array}{l}34.85 / \\
6.67\end{array}$ & $\begin{array}{l}0.65 \pm \\
0.15\end{array}$ & $\begin{array}{l}0.35^{*} \pm \\
0.03\end{array}$ & $\begin{array}{l}1.53 \pm \\
0.18\end{array}$ & $\begin{array}{l}2.81^{*} \pm \\
0.23\end{array}$ \\
\hline 26 & gi|460389468 & $\begin{array}{l}\text { Protein TIC 62, } \\
\text { Solanum lycopersicum }\end{array}$ & 313 & 13 & 5 & $\begin{array}{l}52.96 / \\
7.66\end{array}$ & $\begin{array}{l}1.02 \pm \\
0.14\end{array}$ & $\begin{array}{l}0.20^{*} \pm \\
0.11\end{array}$ & $\begin{array}{l}0.13^{*} \pm \\
0.04\end{array}$ & $\begin{array}{l}0.70 \pm \\
0.17\end{array}$ \\
\hline 27 & gi|460372959 & $\begin{array}{l}\text { Peptidyl-prolyl cis-trans } \\
\text { isomerase CYP38, } \\
\text { Solanum lycopersicum }\end{array}$ & 185 & 17 & 5 & $\begin{array}{l}49.54 / \\
5.00\end{array}$ & $\begin{array}{l}0.92 \pm \\
0.12\end{array}$ & $\begin{array}{l}1.61 \pm \\
0.38\end{array}$ & $\begin{array}{l}0.26^{*} \pm \\
0.05\end{array}$ & $\begin{array}{l}0.15^{*} \pm \\
0.04\end{array}$ \\
\hline \multicolumn{11}{|c|}{ Carbohydrate metabolism and energy } \\
\hline 28 & gi|469517896 & $\begin{array}{l}\text { Glyceraldehyde-3-phosphate } \\
\text { dehydrogenase, Atropa belladonna }\end{array}$ & 101 & 10 & 4 & $\begin{array}{l}34.16 / \\
6.04\end{array}$ & $\begin{array}{l}0.88 \pm \\
0.11\end{array}$ & $\begin{array}{l}0.98 \pm \\
0.29\end{array}$ & $\begin{array}{l}0.46^{*} \pm \\
0.03\end{array}$ & $\begin{array}{l}0.44^{*} \pm \\
0.13\end{array}$ \\
\hline 29 & gi|460414390 & $\begin{array}{l}\text { ATP synthase delta chain, } \\
\text { Solanum lycopersicum }\end{array}$ & 166 & 6 & 4 & $\begin{array}{l}27.32 / \\
8.90\end{array}$ & $\begin{array}{l}0.49^{*} \pm \\
0.17\end{array}$ & $\begin{array}{l}1.62 \pm \\
0.23\end{array}$ & $\begin{array}{l}0.38^{*} \pm \\
0.05\end{array}$ & $\begin{array}{l}0.11^{*} \pm \\
0.03\end{array}$ \\
\hline 30 & gi|303279681 & $\begin{array}{l}\text { Aryl-al/cohol dehydrogenase } \\
\text { related protein, Micromonas pusilla }\end{array}$ & 54 & 3 & 1 & $\begin{array}{l}41.07 / \\
8.65\end{array}$ & $\begin{array}{l}0.53 \pm \\
0.11\end{array}$ & $\begin{array}{l}1.05 \pm \\
0.21\end{array}$ & $\begin{array}{l}2.49^{*} \pm \\
0.35\end{array}$ & $\begin{array}{l}1.28 \pm \\
0.19\end{array}$ \\
\hline 31 & gi|460397188 & $\begin{array}{l}\text { Thiamine thiazole synthase, } \\
\text { Solanum lycopersicum }\end{array}$ & 142 & 14 & 4 & $\begin{array}{l}37.68 / \\
5.42\end{array}$ & $\begin{array}{l}0.30^{*} \pm \\
0.21\end{array}$ & $\begin{array}{l}3.06^{*} \pm \\
0.09\end{array}$ & $\begin{array}{l}2.25^{*} \pm \\
0.07\end{array}$ & $\begin{array}{l}0.23^{*} \pm \\
0.17\end{array}$ \\
\hline 32 & gi|460365268 & $\begin{array}{l}\text { Biotin carboxylase } 1, \\
\text { Solanum lycopersicum }\end{array}$ & 413 & 13 & 6 & $\begin{array}{l}59.08 / \\
6.52\end{array}$ & $\begin{array}{l}0.68 \pm \\
0.27\end{array}$ & $\begin{array}{l}1.51 \pm \\
0.26\end{array}$ & $\begin{array}{l}0.82 \pm \\
0.08\end{array}$ & $\begin{array}{l}0.37^{*} \pm \\
0.13\end{array}$ \\
\hline 33 & gi|723747143 & $\begin{array}{l}\text { Aconitate hydratase, } \\
\text { Solanum lycopersicum }\end{array}$ & 218 & 5 & 4 & $\begin{array}{l}107.83 / \\
6.52\end{array}$ & $\begin{array}{l}67.86^{*} \pm \\
0.19\end{array}$ & $\begin{array}{l}3.13^{*} \pm \\
0.22\end{array}$ & $\begin{array}{l}0.26^{*} \pm \\
0.02\end{array}$ & $\begin{array}{l}5.77^{*} \pm \\
0.85\end{array}$ \\
\hline 34 & gi|350538543 & $\begin{array}{l}\text { Succinic semialdehyde reductase } \\
\text { isofom 2, Solanum lycopersicum }\end{array}$ & 123 & 7 & 2 & $\begin{array}{l}38.94 / \\
8.50\end{array}$ & $\begin{array}{l}2.01^{*} \pm \\
0.26\end{array}$ & $\begin{array}{l}2.52^{*} \pm \\
0.10\end{array}$ & $\begin{array}{l}1.24 \pm \\
0.09\end{array}$ & $\begin{array}{l}1.06 \pm \\
0.93\end{array}$ \\
\hline 35 & gi|460408278 & Enolase-like, Solanum lycopersicum & 207 & 11 & 4 & $\begin{array}{l}48.21 / \\
5.99\end{array}$ & $\begin{array}{l}3.37^{*} \pm \\
0.29\end{array}$ & $\begin{array}{l}4.38^{*} \pm \\
0.04\end{array}$ & $\begin{array}{l}1.49 \pm \\
0.09\end{array}$ & $\begin{array}{l}1.14 \pm \\
0.14\end{array}$ \\
\hline 36 & gi|460415839 & $\begin{array}{l}\text { Probable ATP synthase } 24 \mathrm{kDa} \\
\text { subunit, Solanum lycopersicum }\end{array}$ & 78 & 5 & 1 & $\begin{array}{l}27.75 / \\
8.69\end{array}$ & $\begin{array}{l}0.44^{*} \pm \\
0.08\end{array}$ & $\begin{array}{l}0.49^{*} \pm \\
0.12\end{array}$ & $\begin{array}{l}1.31 \pm \\
0.09\end{array}$ & $\begin{array}{l}1.02 \pm \\
0.28\end{array}$ \\
\hline 37 & gi|460373820 & $\begin{array}{l}\text { ATP synthase gamma chain, } \\
\text { Solanum lycopersicum }\end{array}$ & 167 & 12 & 3 & $\begin{array}{l}41.75 / \\
8.15\end{array}$ & $\begin{array}{l}1.93 \pm \\
0.33\end{array}$ & $\begin{array}{l}3.80^{*} \pm \\
0.24\end{array}$ & $\begin{array}{l}0.09^{*} \pm \\
0.01\end{array}$ & $\begin{array}{l}0.05^{*} \pm \\
0.01\end{array}$ \\
\hline 38 & gi|460365435 & $\begin{array}{l}\text { Isocitrate dehydrogenase [NADP], } \\
\text { Solanum lycopersicum }\end{array}$ & 172 & 12 & 4 & $\begin{array}{l}47.00 / \\
6.35\end{array}$ & $\begin{array}{l}1.05 \pm \\
0.22\end{array}$ & $\begin{array}{l}0.27^{*} \pm \\
0.12\end{array}$ & $\begin{array}{l}0.21^{*} \pm \\
0.03\end{array}$ & $\begin{array}{l}0.86 \pm \\
0.14\end{array}$ \\
\hline 39 & gi|350535679 & $\begin{array}{l}\text { Cytosolic NADP-malic enzyme, } \\
\text { Solanum lycopersicum }\end{array}$ & 167 & 6 & 3 & $\begin{array}{l}64.63 / \\
5.71\end{array}$ & $\begin{array}{l}2.04^{*} \pm \\
0.20\end{array}$ & $\begin{array}{l}1.20 \pm \\
0.14\end{array}$ & $\begin{array}{l}0.48^{*} \pm \\
0.07\end{array}$ & $\begin{array}{l}0.49^{*} \pm \\
0.20\end{array}$ \\
\hline 40 & gi|31088232 & Chitinase, Solanum lycopersicum & 123 & 18 & 7 & $\begin{array}{l}28.05 / \\
5.93\end{array}$ & $\begin{array}{l}0.82 \pm \\
0.11\end{array}$ & $\begin{array}{l}0.30^{*} \pm \\
0.03\end{array}$ & $\begin{array}{l}1.51 \pm \\
0.31\end{array}$ & $\begin{array}{l}4.12^{*} \pm \\
0.10\end{array}$ \\
\hline \multicolumn{11}{|c|}{ Proteometabolism } \\
\hline 41 & gi|350535160 & $\begin{array}{l}\text { Wound-inducible carboxypeptidase } \\
\text { precursor, Solanum lycopersicum }\end{array}$ & 191 & 5 & 2 & $\begin{array}{l}56.04 / \\
5.84\end{array}$ & $\begin{array}{l}1.14 \pm \\
0.07\end{array}$ & $\begin{array}{l}0.78 \pm \\
0.05\end{array}$ & $\begin{array}{l}3.62^{*} \pm \\
0.30\end{array}$ & $\begin{array}{l}5.27^{*} \pm \\
0.22\end{array}$ \\
\hline 42 & gi|350535160 & $\begin{array}{l}\text { Wound-inducible carboxypeptidase } \\
\text { precursor, Solanum lycopersicum }\end{array}$ & 177 & 5 & 3 & $\begin{array}{l}56.04 / \\
5.84\end{array}$ & $\begin{array}{l}1.07 \pm \\
0.17\end{array}$ & $\begin{array}{l}0.48^{*} \pm \\
0.02\end{array}$ & $\begin{array}{l}2.72^{*} \pm \\
0.19\end{array}$ & $\begin{array}{l}6.05^{*} \pm \\
0.30\end{array}$ \\
\hline 43 & gi|350534564 & $\begin{array}{l}265 \text { protease regulatory subunit } \\
6 \mathrm{~A} \text { homolog, Solanum lycopersicum }\end{array}$ & 253 & 17 & 6 & $\begin{array}{l}47.70 / \\
4.94\end{array}$ & $\begin{array}{l}1.18 \pm \\
0.05\end{array}$ & $\begin{array}{l}0.78 \pm \\
0.25\end{array}$ & $\begin{array}{l}0.20^{*} \pm \\
0.07\end{array}$ & $\begin{array}{l}0.30^{*} \pm \\
0.04\end{array}$ \\
\hline 44 & gi|460393754 & $\begin{array}{l}26 \mathrm{~S} \text { protease regulatory subunit } \\
6 \mathrm{~B} \text { homolog, Solanum lycopersicum }\end{array}$ & 198 & 7 & 2 & $\begin{array}{l}46.80 / \\
5.63\end{array}$ & $\begin{array}{l}1.24 \pm \\
0.40\end{array}$ & $\begin{array}{l}0.38^{*} \pm \\
0.13\end{array}$ & $\begin{array}{l}0.33^{*} \pm \\
0.23\end{array}$ & $\begin{array}{l}0.91 \pm \\
0.34\end{array}$ \\
\hline 45 & gi|460400419 & $\begin{array}{l}\text { Elongation factor G, Solanum } \\
\text { lycopersicum }\end{array}$ & 258 & 11 & 5 & $\begin{array}{l}86.79 / \\
5.45\end{array}$ & $\begin{array}{l}3.75^{*} \pm \\
0.31\end{array}$ & $\begin{array}{l}0.53 \pm \\
0.02\end{array}$ & $\begin{array}{l}0.47^{*} \pm \\
0.01\end{array}$ & $\begin{array}{l}3.29^{*} \pm \\
0.39\end{array}$ \\
\hline 46 & gi|460415494 & $\begin{array}{l}\text { Eukaryotic initiation factor 4A-2, } \\
\text { Solanum lycopersicum }\end{array}$ & 370 & 18 & 7 & $\begin{array}{l}47.10 / \\
5.46\end{array}$ & $\begin{array}{l}1.82 \pm \\
0.06\end{array}$ & $\begin{array}{l}1.72 \pm \\
0.15\end{array}$ & $\begin{array}{l}0.35^{*} \pm \\
0.02\end{array}$ & $\begin{array}{l}0.37^{*} \pm \\
0.02\end{array}$ \\
\hline 47 & gi|460399092 & $\begin{array}{l}\text { Eukaryotic initiation factor } 4 \mathrm{~A}-2 \text {, } \\
\text { Solanum lycopersicum }\end{array}$ & 304 & 13 & 4 & $\begin{array}{l}47.14 / \\
5.54\end{array}$ & $\begin{array}{l}1.22 \pm \\
0.22\end{array}$ & $\begin{array}{l}2.73^{*} \pm \\
0.07\end{array}$ & $\begin{array}{l}0.49^{*} \pm \\
0.22\end{array}$ & $\begin{array}{l}0.22^{*} \pm \\
0.05\end{array}$ \\
\hline 48 & gi|460391817 & $\begin{array}{l}\text { Elongation factor TuB, } \\
\text { Solanum lycopersicum }\end{array}$ & 125 & 5 & 2 & $\begin{array}{l}56.29 / \\
6.69\end{array}$ & $\begin{array}{l}0.62 \pm \\
0.16\end{array}$ & $\begin{array}{l}4.33^{*} \pm \\
0.23\end{array}$ & $\begin{array}{l}2.45^{*} \pm \\
0.23\end{array}$ & $\begin{array}{l}0.34^{*} \pm \\
0.03\end{array}$ \\
\hline
\end{tabular}


Table 1 A total of 86 differentially expressed proteins identified in resistant and susceptible tomato cultivars after TYLCV infection (Continued)

\begin{tabular}{|c|c|c|c|c|c|c|c|c|c|c|}
\hline 49 & gi|460399098 & $\begin{array}{l}\text { Elongation factor } 2 \text { isoform } \times 1 \text {, } \\
\text { Solanum lycopersicum }\end{array}$ & 248 & 7 & 4 & $\begin{array}{l}94.97 / \\
5.84\end{array}$ & $\begin{array}{l}1.35 \pm \\
0.24\end{array}$ & $\begin{array}{l}3.39^{*} \pm \\
0.23\end{array}$ & $\begin{array}{l}3.06^{*} \pm \\
0.11\end{array}$ & $\begin{array}{l}1.22 \pm \\
0.19\end{array}$ \\
\hline 50 & gi|460396224 & $\begin{array}{l}\text { Eukaryotic translation initiation } \\
\text { factor } 3 \text { subunit } \mathrm{K} \\
\text { Solanum lycopersicum }\end{array}$ & 134 & 11 & 2 & $\begin{array}{l}26.55 / \\
5.28\end{array}$ & $\begin{array}{l}0.46^{*} \pm \\
0.03\end{array}$ & $\begin{array}{l}1.12 \pm \\
0.17\end{array}$ & $\begin{array}{l}2.80^{*} \pm \\
0.26\end{array}$ & $\begin{array}{l}1.15 \pm \\
0.12\end{array}$ \\
\hline 51 & gi|460391351 & $\begin{array}{l}\text { Cell division cycle protein } 48 \\
\text { homolog, Solanum lycopersicum }\end{array}$ & 172 & 9 & 5 & $\begin{array}{l}90.15 / \\
5.10\end{array}$ & $\begin{array}{l}24.39^{*} \pm \\
0.39\end{array}$ & $\begin{array}{l}1.57 \pm \\
0.13\end{array}$ & $\begin{array}{l}0.38^{*} \pm \\
0.04\end{array}$ & $\begin{array}{l}5.90^{*} \pm \\
0.81\end{array}$ \\
\hline 52 & gi|460411520 & $\begin{array}{l}\text { Cell division cycle protein } 48 \\
\text { homolog, Solanum lycopersicum }\end{array}$ & 138 & 5 & 3 & $\begin{array}{l}90.25 / \\
5.20\end{array}$ & $\begin{array}{l}5.85^{*} \pm \\
0.22\end{array}$ & $\begin{array}{l}0.91 \pm \\
0.08\end{array}$ & $\begin{array}{l}1.09 \pm \\
0.04\end{array}$ & $\begin{array}{l}7.00^{*} \pm \\
0.60\end{array}$ \\
\hline 53 & gi|2492530 & $\begin{array}{l}\text { Leucine aminopeptidase } 2, \\
\text { Solanum lycopersicum }\end{array}$ & 79 & 8 & 3 & $\begin{array}{l}60.08 / \\
8.18\end{array}$ & $\begin{array}{l}4.80^{*} \pm \\
0.15\end{array}$ & $\begin{array}{l}2.68^{*} \pm \\
0.29\end{array}$ & $\begin{array}{l}0.81 \pm \\
0.07\end{array}$ & $\begin{array}{l}1.46 \pm \\
0.07\end{array}$ \\
\hline 54 & gi|350536267 & $\begin{array}{l}\text { Subtilisin-like protease precursor, } \\
\text { Solanum lycopersicum }\end{array}$ & 301 & 5 & 3 & $\begin{array}{l}79.57 / \\
6.25\end{array}$ & $\begin{array}{l}0.24^{*} \pm \\
0.02\end{array}$ & $\begin{array}{l}0.07^{*} \pm \\
0.01\end{array}$ & $\begin{array}{l}4.17^{*} \pm \\
0.29\end{array}$ & $\begin{array}{l}14.46^{*} \pm \\
0.40\end{array}$ \\
\hline 55 & gi|460381101 & $\begin{array}{l}28 \text { kDa ribonucleoprotein, } \\
\text { Solanum lycopersicum }\end{array}$ & 100 & 8 & 3 & $\begin{array}{l}32.69 / \\
4.70\end{array}$ & $\begin{array}{l}1.11 \pm \\
0.19\end{array}$ & $\begin{array}{l}1.15 \pm \\
0.31\end{array}$ & $\begin{array}{l}2.17^{*} \pm \\
0.70\end{array}$ & $\begin{array}{l}2.05^{*} \pm \\
0.25\end{array}$ \\
\hline \multicolumn{11}{|c|}{ Amino acid metabolism } \\
\hline 56 & gi|723717714 & $\begin{array}{l}\text { Phosphoglycerate kinase, } \\
\text { Solanum lycopersicum }\end{array}$ & 275 & 17 & 6 & $\begin{array}{l}42.26 / \\
5.78\end{array}$ & $\begin{array}{l}1.24 \pm \\
0.46\end{array}$ & $\begin{array}{l}0.47^{*} \pm \\
0.02\end{array}$ & $\begin{array}{l}0.42^{*} \pm \\
0.02\end{array}$ & $\begin{array}{l}1.11 \pm \\
0.41\end{array}$ \\
\hline 57 & gi|460404838 & $\begin{array}{l}\text { Adenosylhomocysteinase, } \\
\text { Solanum lycopersicum }\end{array}$ & 119 & 12 & 4 & $\begin{array}{l}53.59 / \\
5.57\end{array}$ & $\begin{array}{l}1.10 \pm \\
0.34\end{array}$ & $\begin{array}{l}0.53 \pm \\
0.16\end{array}$ & $\begin{array}{l}0.21^{*} \pm \\
0.06\end{array}$ & $\begin{array}{l}0.45^{*} \pm \\
0.19\end{array}$ \\
\hline 58 & gi|460395681 & $\begin{array}{l}\text { Ketol-acid reductoisomerase, } \\
\text { Solanum lycopersicum }\end{array}$ & 68 & 5 & 2 & $\begin{array}{l}64.19 / \\
6.31\end{array}$ & $\begin{array}{l}0.83 \pm \\
0.40\end{array}$ & $\begin{array}{l}0.34^{*} \pm \\
0.20\end{array}$ & $\begin{array}{l}0.39^{*} \pm \\
0.09\end{array}$ & $\begin{array}{l}0.97 \pm \\
0.21\end{array}$ \\
\hline 59 & gi|460415192 & $\begin{array}{l}\text { S-adenosylmethionine } \\
\text { synthase 2, Solanum lycopersicum }\end{array}$ & 207 & 7 & 2 & $\begin{array}{l}43.51 / \\
5.41\end{array}$ & $\begin{array}{l}2.09^{*} \pm \\
0.26\end{array}$ & $\begin{array}{l}2.04^{*} \pm \\
0.07\end{array}$ & $\begin{array}{l}0.64 \pm \\
0.06\end{array}$ & $\begin{array}{l}0.86 \pm \\
0.09\end{array}$ \\
\hline 60 & gi|460399143 & $\begin{array}{l}\text { Glycine dehydrogenase } \\
\text { (decarboxylating), } \\
\text { Solanum lycopersicum }\end{array}$ & 192 & 9 & 6 & $\begin{array}{l}114.02 / \\
6.69\end{array}$ & $\begin{array}{l}1.90 \pm \\
0.14\end{array}$ & $\begin{array}{l}1.39 \pm \\
0.08\end{array}$ & $\begin{array}{l}4.02^{*} \pm \\
0.25\end{array}$ & $\begin{array}{l}5.51^{*} \pm \\
0.19\end{array}$ \\
\hline 61 & gi|460399143 & $\begin{array}{l}\text { Glycine dehydrogenase } \\
\text { (decarboxylating), } \\
\text { Solanum lycopersicum }\end{array}$ & 153 & 7 & 5 & $\begin{array}{l}114.02 / \\
6.69\end{array}$ & $\begin{array}{l}3.80^{*} \pm \\
0.19\end{array}$ & $\begin{array}{l}5.08^{*} \pm \\
0.31\end{array}$ & $\begin{array}{l}6.81^{*} \pm \\
0.38\end{array}$ & $\begin{array}{l}5.09^{*} \pm \\
0.21\end{array}$ \\
\hline 62 & gi|460370413 & $\begin{array}{l}\text { Glycine dehydrogenase, } \\
\text { Solanum lycopersicum }\end{array}$ & 183 & 9 & 3 & $\begin{array}{l}42.52 / \\
6.56\end{array}$ & $\begin{array}{l}0.28^{*} \pm \\
0.02\end{array}$ & $\begin{array}{l}12.57^{*} \pm \\
0.28\end{array}$ & $\begin{array}{l}3.33^{*} \pm \\
0.16\end{array}$ & $\begin{array}{l}0.07^{*} \pm \\
0.02\end{array}$ \\
\hline 63 & gi|170458 & $\begin{array}{l}\text { Threonine deaminase, partial, } \\
\text { Solanum lycopersicum }\end{array}$ & 194 & 9 & 4 & $\begin{array}{l}65.05 / \\
5.26\end{array}$ & $\begin{array}{l}1.01 \pm \\
0.01\end{array}$ & $\begin{array}{l}0.82 \pm \\
0.04\end{array}$ & $\begin{array}{l}5.90^{*} \pm \\
0.09\end{array}$ & $\begin{array}{l}7.29^{*} \pm \\
0.29\end{array}$ \\
\hline 64 & gi|170458 & $\begin{array}{l}\text { Threonine deaminase, partial, } \\
\text { Solanum lycopersicum }\end{array}$ & 443 & 18 & 7 & $\begin{array}{l}65.05 / \\
5.26\end{array}$ & $\begin{array}{l}0.22^{*} \pm \\
0.01\end{array}$ & $\begin{array}{l}0.40^{*} \pm \\
0.02\end{array}$ & $\begin{array}{l}5.28^{*} \pm \\
0.62\end{array}$ & $\begin{array}{l}2.96^{*} \pm \\
0.28\end{array}$ \\
\hline 65 & gi|170458 & $\begin{array}{l}\text { Threonine deaminase, partial, } \\
\text { Solanum lycopersicum }\end{array}$ & 175 & 7 & 3 & $\begin{array}{l}65.05 / \\
5.26\end{array}$ & $\begin{array}{l}0.97 \pm \\
0.01\end{array}$ & $\begin{array}{l}0.55 \pm \\
0.02\end{array}$ & $\begin{array}{l}4.35^{*} \pm \\
0.03\end{array}$ & $\begin{array}{l}7.62^{*} \pm \\
0.14\end{array}$ \\
\hline 66 & gi|460398434 & $\begin{array}{l}\text { Cysteine synthase, Solanum } \\
\text { lycopersicum }\end{array}$ & 317 & 20 & 4 & $\begin{array}{l}41.26 / \\
5.41\end{array}$ & $\begin{array}{l}0.99 \pm \\
0.02\end{array}$ & $\begin{array}{l}6.39^{*} \pm \\
0.21\end{array}$ & $\begin{array}{l}2.11^{*} \pm \\
0.22\end{array}$ & $\begin{array}{l}0.33^{*} \pm \\
0.04\end{array}$ \\
\hline 67 & gi|460404180 & $\begin{array}{l}\text { Cysteine synthase, Solanum } \\
\text { lycopersicum }\end{array}$ & 274 & 17 & 5 & $\begin{array}{l}34.34 / \\
5.93\end{array}$ & $\begin{array}{l}1.89 \pm \\
0.13\end{array}$ & $\begin{array}{l}0.63 \pm \\
0.38\end{array}$ & $\begin{array}{l}0.33^{*} \pm \\
0.16\end{array}$ & $\begin{array}{l}1.09 \pm \\
0.19\end{array}$ \\
\hline \multicolumn{11}{|c|}{ Chaperones } \\
\hline 68 & gi|460389504 & $\begin{array}{l}\text { Protein disulfide-isomerase-like, } \\
\text { Solanum lycopersicum }\end{array}$ & 82 & 6 & 2 & $\begin{array}{l}55.11 / \\
4.81\end{array}$ & $\begin{array}{l}0.53 \pm \\
0.02\end{array}$ & $\begin{array}{l}0.55 \pm \\
0.01\end{array}$ & $\begin{array}{l}3.51^{*} \pm \\
0.28\end{array}$ & $\begin{array}{l}3.39^{*} \pm \\
0.22\end{array}$ \\
\hline 69 & gi|460395973 & $\begin{array}{l}\text { Heat shock protein } 83 \text {, Solanum } \\
\text { lycopersicum }\end{array}$ & 76 & 1 & 1 & $\begin{array}{l}90.77 / \\
5.23\end{array}$ & $\begin{array}{l}0.96 \pm \\
0.04\end{array}$ & $\begin{array}{l}1.99 \pm \\
0.03\end{array}$ & $\begin{array}{l}19.73^{*} \pm \\
0.24\end{array}$ & $\begin{array}{l}9.53^{*} \pm \\
0.23\end{array}$ \\
\hline 70 & gi|460395973 & $\begin{array}{l}\text { Heat shock protein } 83 \text {, Solanum } \\
\text { lycopersicum }\end{array}$ & 193 & 3 & 3 & $\begin{array}{l}90.77 / \\
5.23\end{array}$ & $\begin{array}{l}1.24 \pm \\
0.23\end{array}$ & $\begin{array}{l}3.10^{*} \pm \\
0.37\end{array}$ & $\begin{array}{l}2.07^{*} \pm \\
0.26\end{array}$ & $\begin{array}{l}0.82 \pm \\
0.07\end{array}$ \\
\hline 71 & gi|762844 & Hsc70, Solanum lycopersicum & 115 & 4 & 2 & $\begin{array}{l}71.87 / \\
5.18\end{array}$ & $\begin{array}{l}5.38^{*} \pm \\
0.40\end{array}$ & $\begin{array}{l}0.60 \pm \\
0.15\end{array}$ & $\begin{array}{l}1.04 \pm \\
0.28\end{array}$ & $\begin{array}{l}9.20^{*} \pm \\
0.21\end{array}$ \\
\hline 72 & gi|170386 & $\begin{array}{l}\text { Glucose-regulated protein } 78, \\
\text { Solanum lycopersicum }\end{array}$ & 211 & 12 & 3 & $\begin{array}{l}41.32 / \\
8.51\end{array}$ & $\begin{array}{l}2.45^{*} \pm \\
0.40\end{array}$ & $\begin{array}{l}0.73 \pm \\
0.14\end{array}$ & $\begin{array}{l}1.31 \pm \\
0.26\end{array}$ & $\begin{array}{l}4.32^{*} \pm \\
0.41\end{array}$ \\
\hline
\end{tabular}


Table 1 A total of 86 differentially expressed proteins identified in resistant and susceptible tomato cultivars after TYLCV infection (Continued)

\begin{tabular}{|c|c|c|c|c|c|c|c|c|c|c|}
\hline 73 & gi|145341034 & $\begin{array}{l}\text { AAA-metalloprotease FtsH, } \\
\text { Ostreococcus lucimarinus }\end{array}$ & 131 & 6 & 4 & $\begin{array}{l}67.77 / \\
5.23\end{array}$ & $\begin{array}{l}0.92 \pm \\
0.05\end{array}$ & $\begin{array}{l}0.63 \pm \\
0.29\end{array}$ & $\begin{array}{l}0.44^{*} \pm \\
0.01\end{array}$ & $\begin{array}{l}0.75 \pm \\
0.32\end{array}$ \\
\hline \multicolumn{11}{|c|}{ Signal transduction } \\
\hline 74 & gi|1168191 & $\begin{array}{l}\text { 14-3-3 protein } 4 \text { OS, Solanum } \\
\text { lycopersicum }\end{array}$ & 58 & 25 & 4 & $\begin{array}{l}29.40 / \\
4.69\end{array}$ & $\begin{array}{l}0.78 \pm \\
0.33\end{array}$ & $\begin{array}{l}0.67 \pm \\
0.29\end{array}$ & $\begin{array}{l}0.10^{*} \pm \\
0.04\end{array}$ & $\begin{array}{l}0.11^{*} \pm \\
0.05\end{array}$ \\
\hline 75 & gi|3041662 & $\begin{array}{l}\text { 14-3-3 protein 3, Solanum } \\
\text { lycopersicum }\end{array}$ & 165 & 12 & 2 & $\begin{array}{l}29.40 / \\
4.74\end{array}$ & $\begin{array}{l}0.56 \pm \\
0.23\end{array}$ & $\begin{array}{l}1.33 \pm \\
0.24\end{array}$ & $\begin{array}{l}0.21^{*} \pm \\
0.04\end{array}$ & $\begin{array}{l}0.08^{*} \pm \\
0.02\end{array}$ \\
\hline 76 & gi|460405902 & $\begin{array}{l}\text { Plasma membrane-associated } \\
\text { cation-binding protein 1, } \\
\text { Solanum lycopersicum }\end{array}$ & 95 & 6 & 1 & $\begin{array}{l}21.98 / \\
5.03\end{array}$ & $\begin{array}{l}1.71 \pm \\
0.37\end{array}$ & $\begin{array}{l}0.99 \pm \\
0.19\end{array}$ & $\begin{array}{l}0.20^{*} \pm \\
0.04\end{array}$ & $\begin{array}{l}0.34^{*} \pm \\
0.04\end{array}$ \\
\hline 77 & gi|590715109 & $\begin{array}{l}\text { Transducin family protein/WD- } 40 \\
\text { repeat family protein isoform } 1 \text {, } \\
\text { Theobroma cacao }\end{array}$ & 57 & 2 & 1 & $\begin{array}{l}87.16 / \\
6.40\end{array}$ & $\begin{array}{l}0.82 \pm \\
0.01\end{array}$ & $\begin{array}{l}0.18^{*} \pm \\
0.01\end{array}$ & $\begin{array}{l}2.87^{*} \pm \\
0.03\end{array}$ & $\begin{array}{l}12.76^{*} \pm \\
0.11\end{array}$ \\
\hline 78 & gi|460393840 & $\begin{array}{l}\text { Proliferation-associated protein } \\
\text { 2G4-like, Solanum lycopersicum }\end{array}$ & 134 & 7 & 2 & $\begin{array}{l}43.07 / \\
6.41\end{array}$ & $\begin{array}{l}2.16^{*} \pm \\
0.17\end{array}$ & $\begin{array}{l}0.59 \pm \\
0.15\end{array}$ & $\begin{array}{l}0.27^{*} \pm \\
0.09\end{array}$ & $\begin{array}{l}0.97 \pm \\
0.19\end{array}$ \\
\hline 79 & gi|525314284 & $\begin{array}{l}\text { Hop-interacting protein THI113, } \\
\text { Solanum lycopersicum }\end{array}$ & 117 & 10 & 2 & $\begin{array}{l}37.34 / \\
5.82\end{array}$ & $\begin{array}{l}0.93 \pm \\
0.14\end{array}$ & $\begin{array}{l}0.11^{*} \pm \\
0.07\end{array}$ & $\begin{array}{l}0.24^{*} \pm \\
0.18\end{array}$ & $\begin{array}{l}1.96 \pm \\
0.10\end{array}$ \\
\hline \multicolumn{11}{|c|}{ Detoxification and antioxidation } \\
\hline 80 & gi|350536897 & $\begin{array}{l}\text { Cytosolic ascorbate peroxidase } 1, \\
\text { Solanum lycopersicum }\end{array}$ & 113 & 14 & 2 & $\begin{array}{l}27.73 / \\
5.61\end{array}$ & $\begin{array}{l}1.54 \pm \\
0.26\end{array}$ & $\begin{array}{l}0.66 \pm \\
0.06\end{array}$ & $\begin{array}{l}0.42^{*} \pm \\
0.09\end{array}$ & $\begin{array}{l}0.96 \pm \\
0.09\end{array}$ \\
\hline 81 & gi|350536897 & $\begin{array}{l}\text { Cytosolic ascorbate peroxidase 1, } \\
\text { Solanum lycopersicum }\end{array}$ & 115 & 7 & 1 & $\begin{array}{l}27.73 / \\
5.61\end{array}$ & $\begin{array}{l}7.20^{*} \pm \\
0.13\end{array}$ & $\begin{array}{l}7.42^{*} \pm \\
0.32\end{array}$ & $\begin{array}{l}6.03^{*} \pm \\
0.16\end{array}$ & $\begin{array}{l}5.85^{*} \pm \\
0.07\end{array}$ \\
\hline 82 & gi|350539113 & $\begin{array}{l}\text { Ascorbate peroxidase, Solanum } \\
\text { lycopersicum }\end{array}$ & 141 & 5 & 2 & $\begin{array}{l}42.38 / \\
8.65\end{array}$ & $\begin{array}{l}1.90 \pm \\
0.20\end{array}$ & $\begin{array}{l}0.75 \pm \\
0.18\end{array}$ & $\begin{array}{l}0.32^{*} \pm \\
0.04\end{array}$ & $\begin{array}{l}0.81 \pm \\
0.07\end{array}$ \\
\hline 83 & gi|460373807 & $\begin{array}{l}\text { Putative lactoylglutathione lyase, } \\
\text { Solanum lycopersicum }\end{array}$ & 126 & 15 & 5 & $\begin{array}{l}32.95 / \\
5.95\end{array}$ & $\begin{array}{l}0.82 \pm \\
0.22\end{array}$ & $\begin{array}{l}0.17^{*} \pm \\
0.07\end{array}$ & $\begin{array}{l}0.44^{*} \pm \\
0.21\end{array}$ & $\begin{array}{l}2.05^{*} \pm \\
0.24\end{array}$ \\
\hline 84 & gi|50400860 & $\begin{array}{l}\text { Monodehydroascorbate reductase, } \\
\text { Solanum lycopersicum }\end{array}$ & 255 & 17 & 5 & $\begin{array}{l}47.12 / \\
5.77\end{array}$ & $\begin{array}{l}0.85 \pm \\
0.07\end{array}$ & $\begin{array}{l}0.49^{*} \pm \\
0.17\end{array}$ & $\begin{array}{l}0.40^{*} \pm \\
0.18\end{array}$ & $\begin{array}{l}0.69 \pm \\
0.16\end{array}$ \\
\hline 85 & gi|251895 & $\begin{array}{l}\text { Polyphenol oxidase, Solanum } \\
\text { lycopersicum }\end{array}$ & 169 & 7 & 5 & $\begin{array}{l}66.83 / \\
6.61\end{array}$ & $\begin{array}{l}1.96 \pm \\
0.06\end{array}$ & $\begin{array}{l}2.87^{*} \pm \\
0.04\end{array}$ & $\begin{array}{l}15.32^{*} \pm \\
0.10\end{array}$ & $\begin{array}{l}10.49^{*} \pm \\
0.42\end{array}$ \\
\hline 86 & gi|460397526 & $\begin{array}{l}\text { Heme-binding protein } 2 \text {, Solanum } \\
\text { lycopersicum }\end{array}$ & 183 & 17 & 3 & $\begin{array}{l}26.12 / \\
7.59\end{array}$ & $\begin{array}{l}0.84 \pm \\
0.08\end{array}$ & $\begin{array}{l}0.82 \pm \\
0.05\end{array}$ & $\begin{array}{l}4.29^{*} \pm \\
0.25\end{array}$ & $\begin{array}{l}4.41^{*} \pm \\
0.18\end{array}$ \\
\hline
\end{tabular}

a Numbering corresponds to the 2-DE in Fig. 3

${ }^{\mathrm{b}}$ Accession number from the NCBI nr database

'Names and species of the proteins obtained via the MASCOT software from the NCBI nr database

${ }^{\mathrm{d}}$ Molecular weight search (MOWSE) score probability for the entire protein identified by the MASCOT software

'The sequence coverage of identified proteins

fTotal numbers of identified peptides

${ }^{9}$ Molecular weight and isoelectric point of the identified proteins

${ }^{h}$ Protein abundance ratio of Treatment/Control tomato cultivars, with each value representing the mean value \pm SD of three biological replicates

*Indicates significant (more than 2.0 -fold or less than 0.50 -fold) difference between control and treatment tomato cultivars

Genes and Genomes (KEGG) (http://www.kegg.jp/ kegg/pathway.html): 27 photosynthesis (31.4\%), 15 proteometabolism (17.4\%), 13 carbohydrate metabolism and energy (15.1\%), 12 amino acid metabolism (14.0\%), 7 detoxification and antioxidation (8.1\%), 6 signal transduction $(7.0 \%), 6$ chaperones $(7.0 \%)$. The functional classes of identified proteins in two different tomato genotypes 'Zheza-301' and 'Jinpeng-1' were the same (Fig. 5b-c).

Among the 27 proteins involved in photosynthesis, 11 enzymes including $\mathrm{CAB}$ (chlorophyll a-b binding-protein, spots 1-3) [23, 24], OEE1 (oxygen-evolving enhancer protein1, spots 4, 5) $[25,26]$ and LFNR (ferredoxin-NADP reductase, leaf-type isozyme, spots 22,23 ) play important roles in light-dependent reactions (Table 1). The other 16 enzymes, such as ribulose-1,5-bisphosphate carboxylase (RuBisCO, spots 11-14) and carbonic anhydrase (spots 24, 25), participate in the Calvin cycle [27]. Thirteen proteins are involved in carbohydrate metabolism and energy, such as GAPDH (glyceraldehyde 3-phosphate dehydrogenase, spot 28), AH (aconitate hydratase, spot 33), EA (enolase, spot 35), ID (isocitrate dehydrogenase, spot 38) and CHI (chitinase, spot 40). CAR (wound-inducible carboxypeptidase precursor, spots 41, 42), CDC48 (cell division cycle protein 48 homolog, spots 51, 52), PRO (subtilisin-like protease precursor, spot 54) and eukaryotic initiation factor 4A-2 (spots 46, 47) take part in 


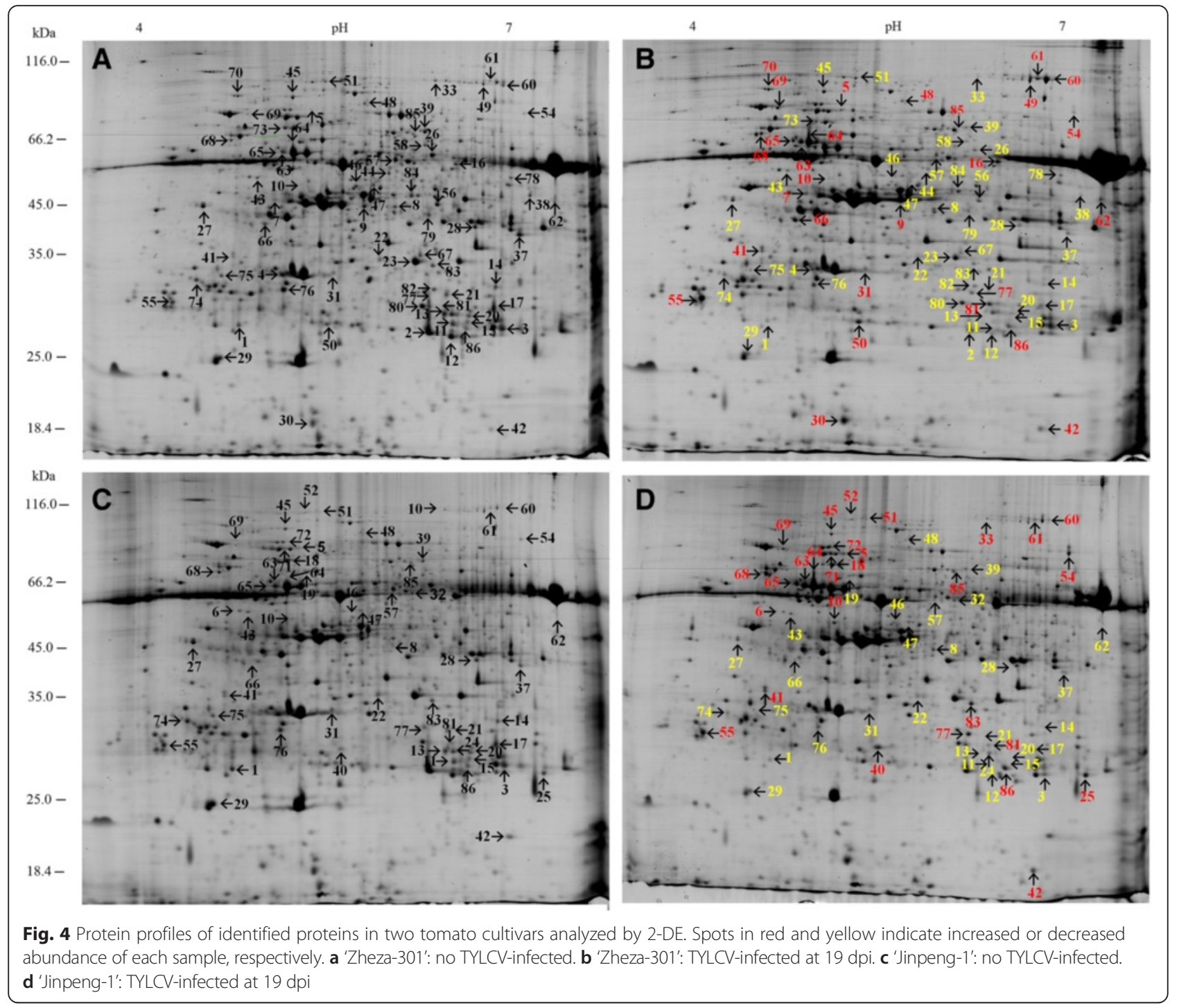

proteometabolism. Several proteins are identified as being involved in signal transduction or as chaperones, such as HSP83 (spots 69, 70), HSC70 (spot 71) and 14-3-3 protein (spots 74, 75). Detoxification and antioxidation are essential for plants to survive. When faced with TYLCV infection, PPO (polyphenol oxidase, spot 85), Glo I (lactoylglutathione lyase, spot 83) and APX (ascorbate peroxidase, spots $80-82$ ) are detected in both tomato genotypes. Twelve proteins are identified as being related to amino acid metabolism, including GLDC (glycine dehydrogenase (decarboxylating), spots 60-62), THD (threonine deaminase, spots 63-65), MAT (S-adenosylmethionine synthase 2, spot 59) and CYS (cysteine synthase, spots 66, 67).

\section{Differentially expressed proteins identified in resistant} and susceptible tomato cultivars after TYLCV infection Expression patterns in terms of the protein abundance ratios of 86 identified proteins were different between the two tomato cultivars. A heat map of differentially expressed protein spots provides an overview of protein expression modification in the two TYLCV-infected tomato genotypes (Fig. 6). In general, most proteins in 'Zheza-301' showed down-regulated expression profiles. In 'Jinpeng-1', the proportions of up- and downregulated proteins were almost the same. In 'Zheza-301', 71 proteins were modulated between the TYLCVinfected and control leaf samples, with the expression levels of 28 proteins increased and 43 proteins decreased. In 'Jinpeng-1', 59 proteins appeared to be altered, and of these 28 and 31 were up-regulated and down-regulated, respectively (Fig. 4). Among the 86 protein spots, expression levels of 17 proteins were upregulated in both 'Zheza-301' and 'Jinpeng-1', including OEE1 (spot 5), HSP83 (spot 69) and PPO (spot 85). A total of 24 protein spots were identified with down-regulated expression levels in both cultivars, including 14- 

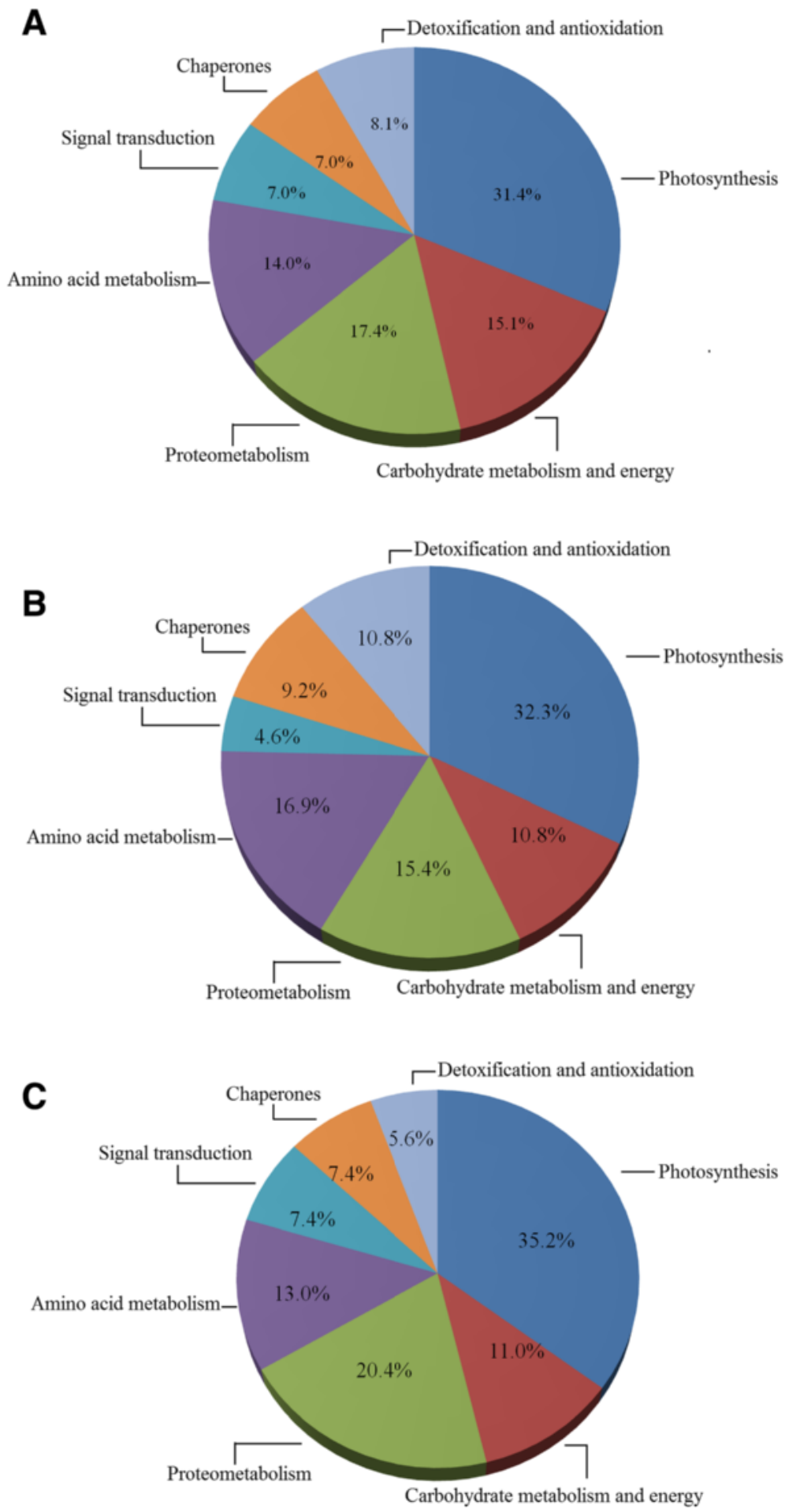

Fig. 5 Functional classification of differentially expressed proteins in the leaves of two tomato cultivars under TYLCV infection. a Proportion of 86 differentially expression proteins identified in two tomato cultivars. $\mathbf{b}$ Proportion of functional classification of differentially expressed proteins in tomato genotypes 'Zheza-301'. c Proportion of functional classification of differentially expressed proteins in genotypes 'Jinpeng-1'

3-3 protein (spots 74, 75) and RuBisCO (spots 11-14). Some proteins showed opposite expression patterns in the two cultivars. The expression levels of spots 48,62 and 66 showed up-regulation in 'Zheza-301', but down-regulation in 'Jinpeng-1' (Table 2). The differences in expression patterns of proteins indicate that several proteins play 


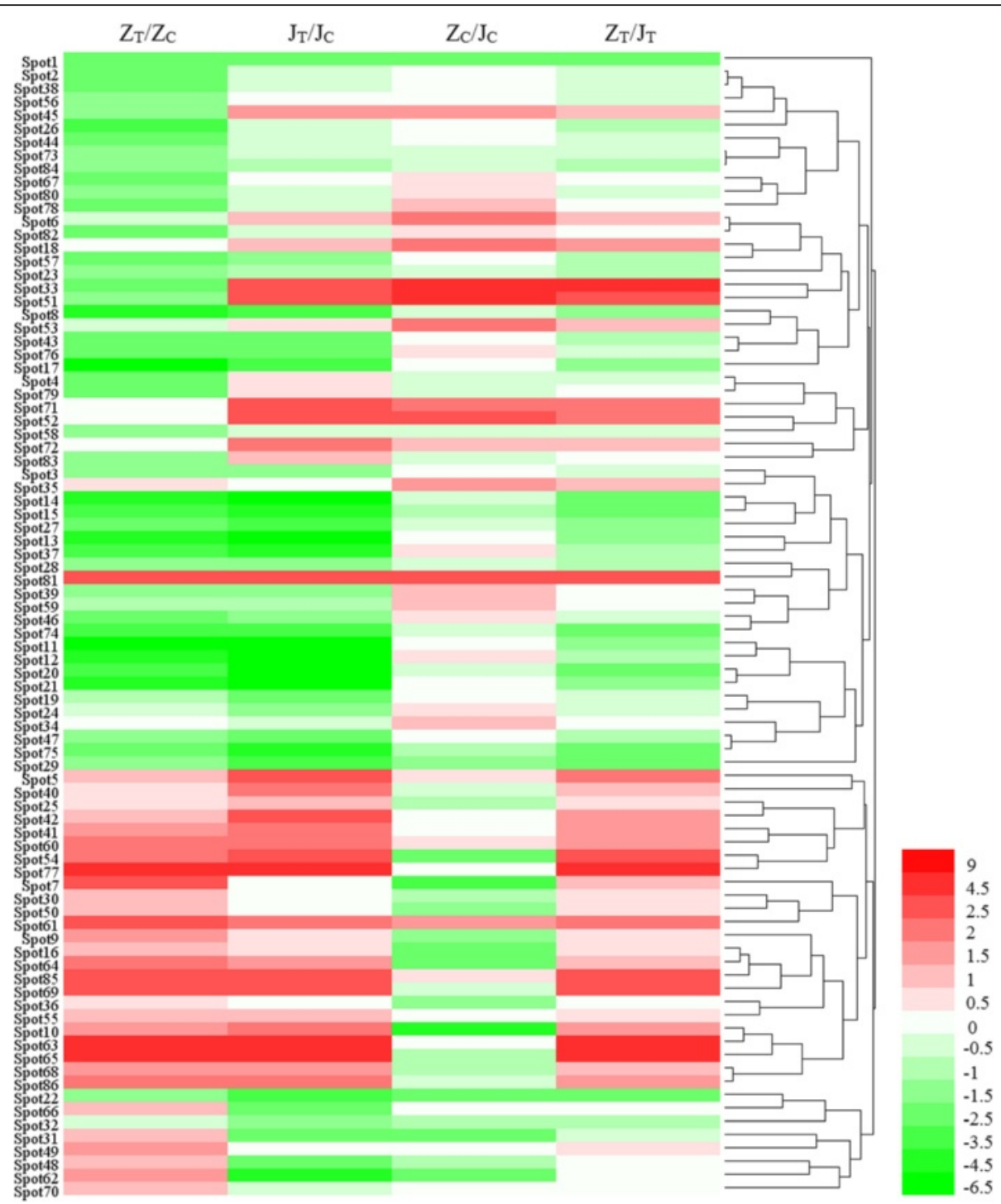

Fig. 6 Heat map representation and hierarchical clustering of 86 identified proteins in resistant cultivar 'Zheza-301' and susceptible cultivar 'Jinpeng-1' after TYLCV infection. The protein abundance ration of each spot was normalized by the log 2 transformed to represent color scores. Red represented high expression, and green represented low expression. Z represented 'Zheza-301', J represented 'Jinpeng-1', T represented 'treatment', C represented 'control'

different roles in resistant and susceptible tomato cultivars in response to TYLCV infection.

\section{Expression analysis of $T y-1$ and $T y-5$ genes after TYLCV infection in tomato}

Two genes, namely, $T y-1$ and $T y-5$, associated with the Ty locus, have been identified in tomatoes. The expression patterns of $T y-1$ and $T y-5$ were analyzed using qRTPCR in 'Zheza-301' and 'Jinpeng-1' tomato cultivars (Fig. 7). In 'Zheza-301', the expression pattern of $T y-5$ was up-regulated at six time points after infection (2, 4, $6,10,15$ and $19 \mathrm{dpi}$ ), and a peak was reached at $15 \mathrm{dpi}$ with a 5-fold increase. The expression level of $T y$ - 1 was not noticeably increased until 19 dpi, when it increased by approximately 3 -fold. The expression patterns of $T y-1$ and $T y-5$ were both up-regulated in 'Jinpeng- 1 '. The expression level peaks of $T y-1$ and $T y-5$ in 'Jinpeng-1' were observed at $2 \mathrm{dpi}$ with a 30 -fold increase and at $10 \mathrm{dpi}$ with a 70 -fold increase, respectively.

\section{Expression profile analysis of proteins involved in TYLCV infection in tomato}

Nineteen genes encoding identified proteins, namely, OEE, CAB, LFNR, ID, AH, EA, GAPDH, CAR, PPO, APX, Glo I, CHI, CDC48, GLDC, CYS, MAT, THD, HSC7O and PRO, were selected on the basis of our 2-DE results and subjected to expression pattern analysis. To determine where the expression of the 19 selected genes 
Table 2 Proteins differentially expressed between resistant and susceptible tomato cultivars

\begin{tabular}{|c|c|c|c|c|}
\hline aspot no. & ${ }^{\mathrm{b}}$ Accession number & ${ }^{c}$ Protein name & ${ }^{d} Z_{T} / Z_{C}$ & ${ }^{d} J_{T} / J_{C}$ \\
\hline \multicolumn{5}{|c|}{ Up-regulated proteins } \\
\hline Spot5 & gi|460372520 & Oxygen-evolving enhancer protein 1 & $2.21^{*} \pm 0.44$ & $10.57^{*} \pm 0.52$ \\
\hline Spot10 & gi|100380 & Ribulose bisphosphate carboxylase activase & $3.25^{*} \pm 0.44$ & $5.57^{*} \pm 0.43$ \\
\hline Spot41 & gi|350535160 & Wound-inducible carboxypeptidase precursor & $3.62^{*} \pm 0.30$ & $5.27^{*} \pm 0.22$ \\
\hline Spot42 & gi|350535160 & Wound-inducible carboxypeptidase precursor & $2.72^{*} \pm 0.19$ & $6.05^{*} \pm 0.30$ \\
\hline Spot54 & gi|350536267 & Subtilisin-like protease precursor & $4.17^{*} \pm 0.29$ & $14.46^{*} \pm 0.40$ \\
\hline Spot55 & gi|460381101 & $28 \mathrm{kDa}$ ribonucleoprotein & $2.17^{*} \pm 0.70$ & $2.05^{*} \pm 0.25$ \\
\hline Spot60 & gi|460399143 & Glycine dehydrogenase (decarboxylating) & $4.02^{*} \pm 0.25$ & $5.51^{*} \pm 0.19$ \\
\hline Spot61 & gi|460399143 & Glycine dehydrogenase (decarboxylating) & $6.81^{*} \pm 0.38$ & $5.09^{*} \pm 0.21$ \\
\hline Spot63 & gi|170458 & Threonine deaminase, partial & $5.90^{*} \pm 0.09$ & $7.29^{*} \pm 0.29$ \\
\hline Spot64 & gi|170458 & Threonine deaminase, partial & $5.28^{*} \pm 0.62$ & $2.96^{*} \pm 0.28$ \\
\hline Spot65 & gi|170458 & Threonine deaminase, partial & $4.35^{*} \pm 0.03$ & $7.62^{*} \pm 0.14$ \\
\hline Spot68 & gi|460389504 & Protein disulfide-isomerase-like & $3.51^{*} \pm 0.28$ & $3.39^{*} \pm 0.22$ \\
\hline Spot69 & gi|460395973 & Heat shock protein 83 & $19.73^{*} \pm 0.24$ & $9.53^{*} \pm 0.23$ \\
\hline Spot77 & gi|590715109 & Transducin family protein / WD-40 repeat family protein isoform 1 & $2.87^{*} \pm 0.03$ & $12.76^{*} \pm 0.11$ \\
\hline Spot81 & gi|350536897 & Cytosolic ascorbate peroxidase 1 & $6.03^{*} \pm 0.16$ & $5.85^{*} \pm 0.07$ \\
\hline Spot85 & gi|251895 & Polyphenol oxidase & $15.32^{*} \pm 0.10$ & $10.49^{*} \pm 0.42$ \\
\hline Spot86 & gi|460397526 & Heme-binding protein 2 & $4.29^{*} \pm 0.25$ & $4.41^{*} \pm 0.18$ \\
\hline \multicolumn{5}{|c|}{ Down-regulated proteins } \\
\hline Spot1 & gi|407970998 & Chlorophyll a-b binding protein 4 & $0.22^{*} \pm 0.13$ & $0.18^{*} \pm 0.09$ \\
\hline Spot3 & gi|460405507 & Chlorophyll a-b binding protein 8 & $0.46^{*} \pm 0.03$ & $0.36^{*} \pm 0.13$ \\
\hline Spot8 & gi|723739979 & Ribulose bisphosphate carboxylase/oxygenase activase & $0.07^{*} \pm 0.05$ & $0.16^{*} \pm 0.01$ \\
\hline Spot11 & gi|488453358 & Ribulose 1,5-bisphosphate carboxylase & $0.04^{*} \pm 0.01$ & $0.01^{*} \pm 0,01$ \\
\hline Spot12 & gi|488453358 & Ribulose 1,5-bisphosphate carboxylase & $0.06^{*} \pm 0.01$ & $0.02^{*} \pm 0.01$ \\
\hline Spot13 & gi|488453358 & Ribulose 1,5-bisphosphate carboxylase & $0.05^{*} \pm 0.01$ & $0.05^{*} \pm 0.01$ \\
\hline Spot14 & gi|488453358 & Ribulose 1,5-bisphosphate carboxylase & $0.09^{*} \pm 0.01$ & $0.04^{*} \pm 0.01$ \\
\hline Spot15 & gi|1293000 & Ribulose-1,5-bisphosphate carboxylase/oxygenase large subunit & $0.10^{*} \pm 0.05$ & $0.06^{*} \pm 0.01$ \\
\hline Spot17 & gi|21069067 & Ribulose 1,5-bisphosphate carboxylase/oxygenase large subunit & $0.02^{*} \pm 0.01$ & $0.09^{*} \pm 0.08$ \\
\hline Spot20 & gi|92087012 & Ribulose bisphosphate carboxylase large chain OS & $0.09^{*} \pm 0.01$ & $0.01^{*} \pm 0.01$ \\
\hline Spot21 & gi|92087012 & Ribulose bisphosphate carboxylase large chain OS & $0.08^{*} \pm 0.01$ & $0.01^{*} \pm 0.01$ \\
\hline Spot22 & gi|460375527 & Ferredoxin-NADP reductase, leaf-type isozyme & $0.42^{*} \pm 0.10$ & $0.14^{*} \pm 0.02$ \\
\hline Spot27 & gi|460372959 & Peptidyl-prolyl cis-trans isomerase CYP38 & $0.26^{*} \pm 0.05$ & $0.15^{*} \pm 0.04$ \\
\hline Spot28 & gi|469517896 & Glyceraldehyde-3-phosphate dehydrogenase & $0.46^{*} \pm 0.03$ & $0.44^{*} \pm 0.13$ \\
\hline Spot29 & gi|460414390 & ATP synthase delta chain & $0.38^{*} \pm 0.05$ & $0.11^{*} \pm 0.03$ \\
\hline Spot37 & gi|460373820 & ATP synthase gamma chain & $0.09^{*} \pm 0.01$ & $0.05^{*} \pm 0.01$ \\
\hline Spot39 & gi|350535679 & Cytosolic NADP-malic enzyme & $0.48^{*} \pm 0.07$ & $0.49^{*} \pm 0.20$ \\
\hline Spot43 & gi|350534564 & $26 \mathrm{~S}$ protease regulatory subunit $6 \mathrm{~A}$ homolog & $0.20^{*} \pm 0.07$ & $0.30^{*} \pm 0.04$ \\
\hline Spot46 & gi|460415494 & Eukaryotic initiation factor $4 \mathrm{~A}-2$ & $0.35^{*} \pm 0.02$ & $0.37^{*} \pm 0.02$ \\
\hline Spot47 & gi|460399092 & Eukaryotic initiation factor $4 \mathrm{~A}-2$ & $0.49^{*} \pm 0.22$ & $0.22^{*} \pm 0.05$ \\
\hline Spot57 & gi|460404838 & Adenosylhomocysteinase & $0.21^{*} \pm 0.06$ & $0.45^{*} \pm 0.19$ \\
\hline Spot74 & gi|1168191.1 & 14-3-3 protein 4 OS & $0.10^{*} \pm 0.04$ & $0.11^{*} \pm 0.05$ \\
\hline Spot75 & gi|3041662 & 14-3-3 protein 3 & $0.21^{*} \pm 0.04$ & $0.08^{*} \pm 0.02$ \\
\hline Spot76 & gi|460405902 & Plasma membrane-associated cation-binding protein 1 & $0.20^{*} \pm 0.04$ & $0.34^{*} \pm 0.04$ \\
\hline
\end{tabular}


Table 2 Proteins differentially expressed between resistant and susceptible tomato cultivars (Continued)

\begin{tabular}{|c|c|c|c|c|}
\hline \multicolumn{5}{|c|}{ Opposite expression proteins } \\
\hline Spot31 & gi|460397188 & Thiamine thiazole synthase & $2.25^{*} \pm 0.07$ & $0.23^{*} \pm 0.17$ \\
\hline Spot33 & gi|7237477143 & Aconitate hydratase & $0.26^{*} \pm 0.02$ & $5.77^{*} \pm 0.85$ \\
\hline Spot45 & gi|460400419 & Elongation factor $\mathrm{G}$ & $0.47^{*} \pm 0.01$ & $3.29^{*} \pm 0.39$ \\
\hline Spot48 & gi|460391817 & Elongation factor TuB & $2.45^{*} \pm 0.23$ & $0.34^{*} \pm 0.03$ \\
\hline Spot51 & gi|460391351 & Cell division cycle protein 48 homolog & $0.38^{*} \pm 0.04$ & $5.90^{*} \pm 0.81$ \\
\hline Spot62 & gi|460370413 & Glycine dehydrogenase & $3.33^{*} \pm 0.16$ & $0.07^{*} \pm 0.02$ \\
\hline Spot66 & gi|460398434 & Cysteine synthase & $2.11^{*} \pm 0.22$ & $0.33^{*} \pm 0.04$ \\
\hline Spot83 & gi|460373807 & Putative lactoylglutathione lyase & $0.44^{*} \pm 0.21$ & $2.05^{*} \pm 0.24$ \\
\hline
\end{tabular}

${ }^{a}$ Numbering corresponds to the 2-DE in Fig. 3

${ }^{\mathrm{b}}$ Accession number from the NCBI nr database

${ }^{c}$ Names of the proteins obtained via the MASCOT software from the NCBI nr database

dProtein abundance ratio of Treatment/Control tomato cultivars, with each value representing the mean value \pm SD of three biological replicates

*Indicates significant (more than 2.0 -foldor less than 0.50 -fold) difference between control and treatment tomato cultivars

varies in different disease infection stages, qRT-PCR was conducted at six time points after infection $(2,4,6,10$, 15 and 19 dpi) (Figs. 8 and 9).

The expression levels of $C H I, A H, H S C 70$ and MAT in early stages (2, 4 and $6 \mathrm{dpi}$ ) were different from those at 19 dpi. At 2, 4 and $6 \mathrm{dpi}, \mathrm{CHI}, A H$ and $H S C 70$ were negatively regulated in 'Zheza-301'. Expression of $C H I$, $A H$ and $H S C 70$ was up-regulated at 19 dpi (Figs. 8 and 9). The expression patterns of the genes that function in detoxification and antioxidation varied among the six infection periods in the two tomato cultivars. Glo I can convert 2-oxoaldehydes into less reactive 2-hydroxyacids by cooperation with Glo II. In 'Zheza-301', the transcription levels of Glo I and APX were decreased at 2 and 4 dpi (Fig. 8). At 19 dpi, the transcription levels of Glo $I$ and $A P X$ in 'Zheza-301' were up-regulated (Fig. 9). The expression patterns of $P P O$ and $P R O$ were negatively and positively regulated, respectively, in both tomato cultivars at all time points after infection. Previous studies have revealed that $\mathrm{CDC} 48$ can impair tobacco mosaic virus (TMV) movement by removing virus-encoded MP from the endoplasmic reticulum transport pathway and by promoting the interference of MP with microtubule dynamics. The expression levels of CDC48 in 'Jinpeng-1' were higher than those in 'Zheza-301' at all time points. At 2, 4 and $6 \mathrm{dpi}$, the expression patterns of $L F N R, A H$, CHI, CDC48, CYS, HSC70 and PPO were downregulated in 'Zheza-301'. By contrast, the expression levels of OEE, CAB, ID, AH, CAR, APX, Glo I, CHI, CDC48, GLDC, THD, HSC70 and PRO were upregulated in 'Zheza-301' at $19 \mathrm{dpi}$. Therefore, these genes may respond to TYLCV infection via a positive regulatory mechanism (Figs. 8 and 9).

\section{Comparative analysis of expression patterns detected using qRT-PCR and 2-DE}

The expression patterns at 19 dpi observed using qRTPCR and 2-DE were compared. In 'Zheza-301', five proteins, namely, OEE, CAR, GLDC, THD and PRO were positively regulated in both qRT-PCR and 2-DE results. In 'Jinpeng-1', the protein abundance of OEE, $\mathrm{AH}, \mathrm{CHI}$, CDC48, THD, HSC70 and Glo I increased. The expression level of LFNR was down-regulated in both analyses. The transcription levels of the genes detected using qRT-PCR were not well correlated with the protein abundance of proteins detected using 2-DE. CAB, which functions in photosynthesis, showed opposite expression patterns in the two analyses. The protein abundance of
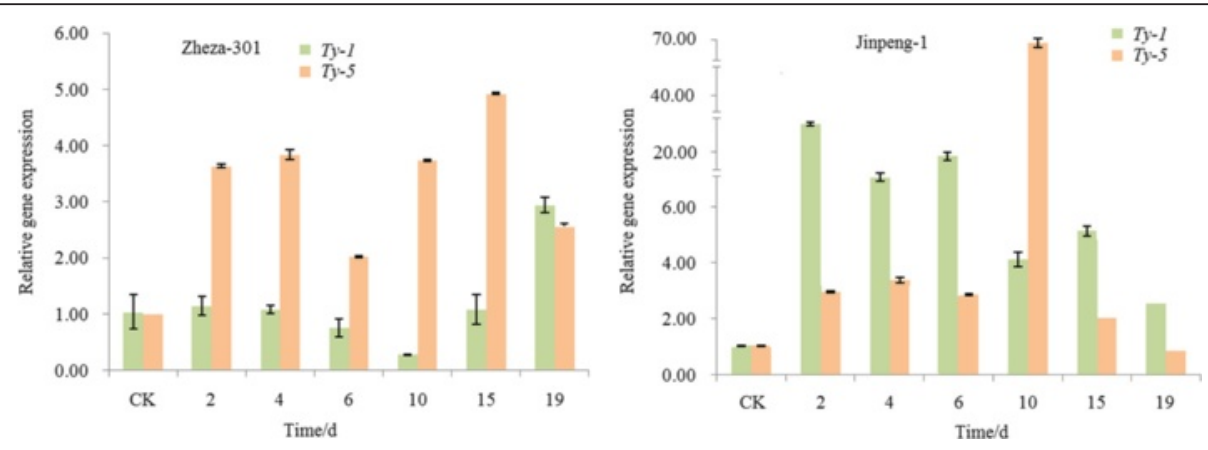

Fig. 7 Relative expression of Ty-1 and Ty-5 after TYLCV infection in tomato 


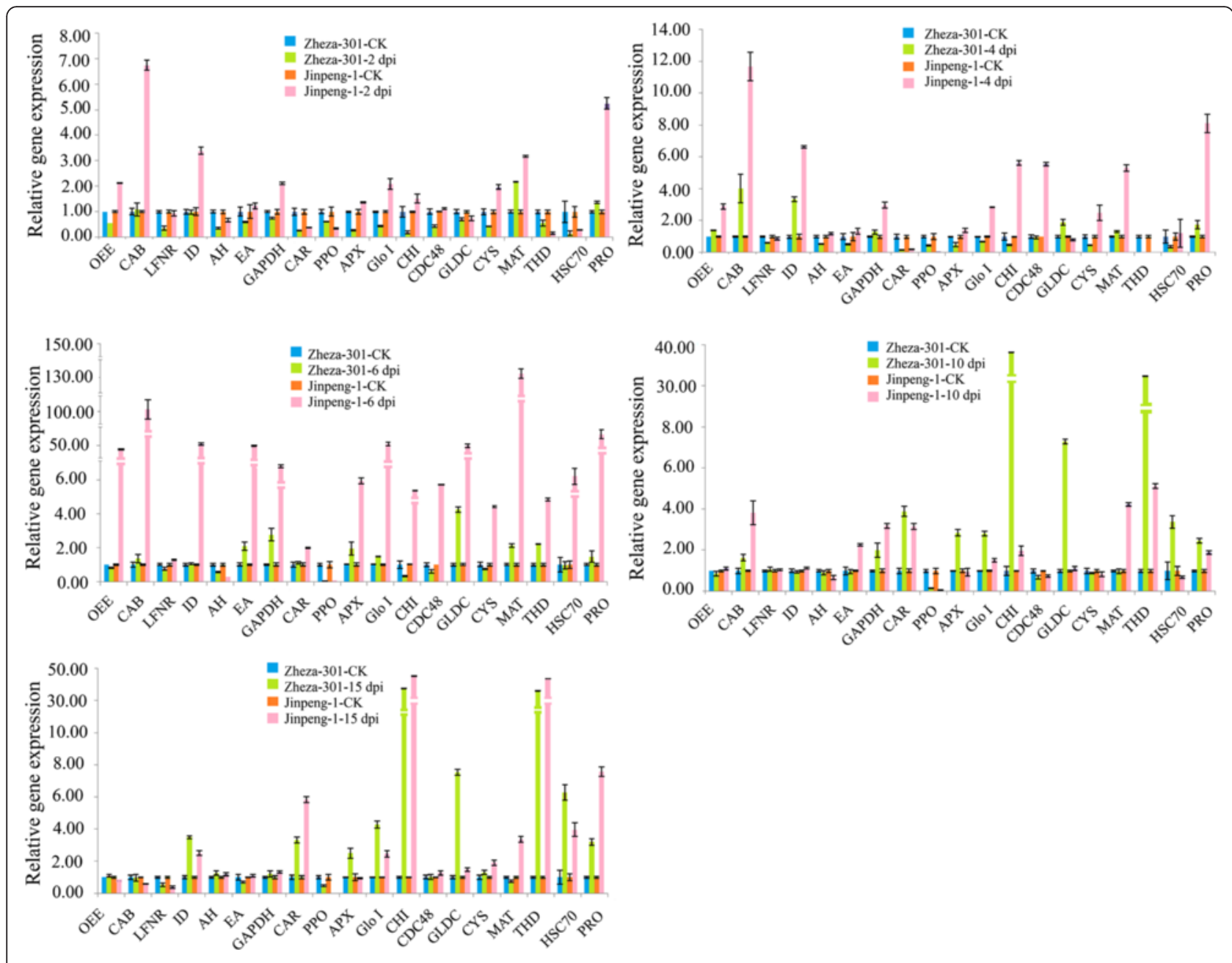

Fig. 8 Expression patterns of 19 selected genes identified by the proteomics analysis at different TYLCV infection stages in tomato

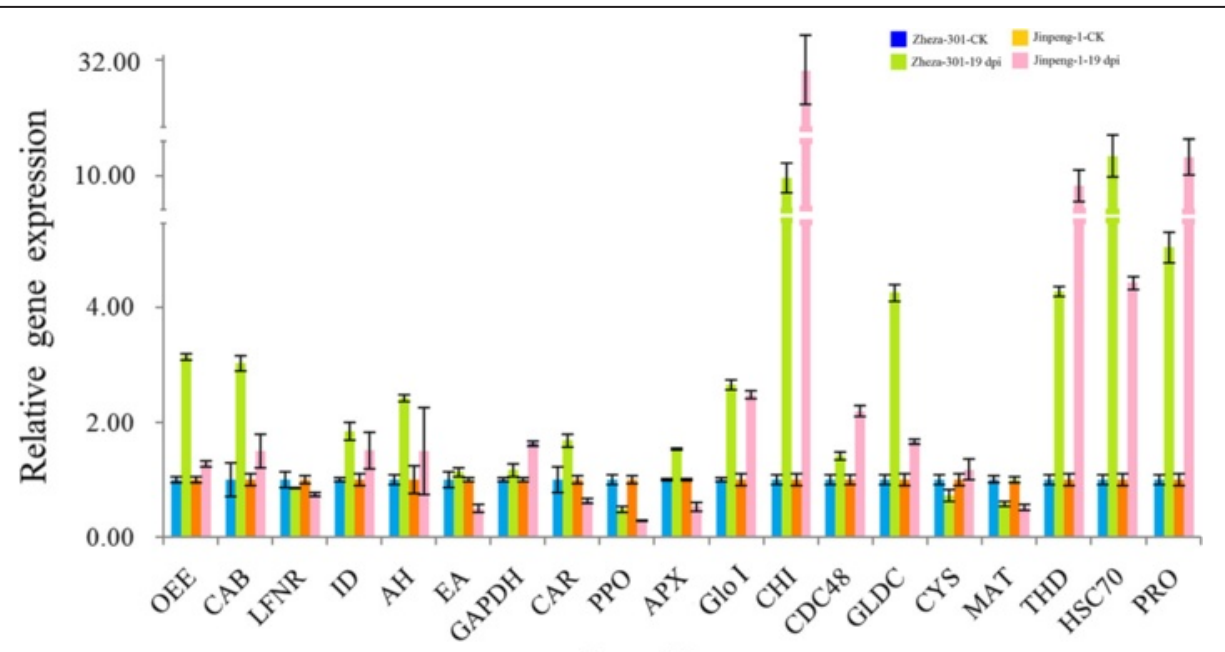

Gene Name

Fig. 9 Relative expression of selected genes in response to TYLCV infection at $19 \mathrm{dpi}$ in tomato 
Glo I in 'Zheza-301' was decreased but transcription level measured by qRT-PCR was increased approximately 3 -fold at $19 \mathrm{dpi}$. In 2-DE, the protein abundance of PPO in the two tomato cultivars increased by approximately 10-fold; in contrast, its transcription levels decreased, as measured using qRT-PCR (Fig. 9, Table 1).

\section{Discussion}

Plants use compensatory strategies to protect themselves from various aggressions by pathogens such as viruses and insects. Infestation with viruliferous whiteflies can cause extensive damage in tomatoes. The proteins identified in control and TYLCV-infected tomato cultivars were classified into different groups, such as defenserelated proteins, chaperones and signal transduction proteins. These groups played different roles in response to TYLCV infection. Several of the proteins identified produced multiple spots with different $p I$ and molecular masses, which indicates the presence of isoforms and posttranslational modification [28]. The ability to resist TYLCV infection varies between different tomato cultivars. Previous studies have shown that 'Zheza-301' and 'Jinpeng-1' exhibit different resistance to TYLCV infection $[15,29]$. After TYLCV infection for two months, 'Zheza-301' had resistance ability with $45.0 \%$ disease incidence and with 9.0 disease indexes. 'Jinpeng-1' showed susceptible to TYLCV infection with $90.0 \%$ disease incidence and 60.9 disease indexes [29]. The two tomato cultivars 'Zheza-301'and 'Jinpeng-1' were thus chosen to further analyze the mechanism of the response to TYLCV infection.

Responses to TYLCV infection in resistant and susceptible tomato cultivars at different stages

Responses to TYLCV infection in tomatoes involve a complicated defense mechanism that is related to transcription factors and gene regulatory networks involving mitogen-activated protein kinases $[15,16]$. Such responses are correlated with anatomical structure [30], tomato genotypes [31-33] and different infection stages [17, 33]. Glick and his colleagues reported that symptoms and responses differ between the early (before 2 weeks) and later (after 4 weeks) stages of TYLCV infection in tomatoes [34]. Tomato plants appear normal after TYLCV infection for 2 weeks, then the leaves of susceptible tomato cultivars become yellow and curly over time, and newly formed leaves are smaller and shriveled. In later stages, whole plants stop growing and this leads to severe yield loss [15, 34]. The response of tomatoes to TYLCV infection should be analyzed at different stages of infection. To determine the genes encoding resistance to TYLCV infection, some research has been conducted at early and later stages of TYLCV infection [16, 17, 33, 35, 36]. A comparative transcriptomic analysis at 3, 5 and $7 \mathrm{dpi}$ has been carried out for resistant and susceptible tomato cultivars [16]. Comparative metabolomics and transcriptomics in response to TYLCV infection at 1, 3, 7 and 14 dpi have also been carried out in two tomato lines $[17,36]$. Adi et al. analyzed stress responses to TYLCV infection in tomato after 4 weeks, which was sufficient to allow the development of differential coat protein (CP) aggregation [33]. Miozzi et al. investigated the transcriptional changes induced by TYLCSV infection after 6 weeks post-infection with typical systemic symptoms [35]. However, responses of tomatoes to TYLCV infection in the middle stage ( $\sim 3$ weeks) have not been described before now.

The responses of 'Zheza-301' (resistant tomato cultivar) and 'Jinpeng-1' (susceptible tomato cultivar) to TYLCV infection are complex and long term. A proteomics approach was used to investigate resistant and susceptible tomato cultivars and to understand the response to TYLCV infection in tomato cultivars in the middle stage ( 3 weeks). At $19 \mathrm{dpi}$, a typical TYLCV phenotype was found in 'Jinpeng-1', but no symptoms were observed in 'Zheza-301'. When stress conditions are encountered, plants can trigger a network of events linked to energy metabolism [37]. Most proteins in this network are involved in photosynthesis, carbohydrate metabolism and energy metabolism. This finding indicates the importance of energy metabolism in response to TYLCV infection. Changes in carbohydrate metabolism are related to energy allocation and long-term defense processes [38]. Upon TYLCV infection, changes in energy metabolism and wound response in tomato plants happen over the whole infection period $[2,7-10]$. The expression patterns of 19 selected genes that encoded proteins with different functions were analyzed through qRT-PCR after 2, 4, 6, 10, 15 and $19 \mathrm{dpi}$. Changes in metabolic pathways and different expression levels were revealed through qRT-PCR and 2$\mathrm{DE}$. The symptoms in the two tomato cultivars were the combined response results caused by TYLCV infection at 19 dpi.

\section{Defense-related proteins}

Recent studies in certain processes of virus-host interactions have reported that some oxidative stress is produced, and base damage is caused by reactive oxygen species (ROS) such as $\mathrm{H}_{2} \mathrm{O}_{2}$ [39-42]. Superoxide dismutase and the ascorbate-glutathione cycle are involved in the breakdown of $\mathrm{H}_{2} \mathrm{O}_{2}$ into $\mathrm{H}_{2} \mathrm{O}$ and $\mathrm{O}_{2}$ [43, 44]. Three isoforms of APX (spots 80-82) were identified as having different expression patterns. Spot 81 showed upregulated expression in terms of protein abundance ratio, which was higher in 'Zheza-301' (Table 1). The expression level of $A P X$ as measured using qRT-PCR was up-regulated at $19 \mathrm{dpi}$, which was consistent with the result of 2-DE. PPOs are ubiquitous in plants and play important roles in plant defense against pests and 
pathogens [45-47]. PPOs can catalyze the oxygendependent oxidation of phenols to quinones, which may have direct antibiotic and cytotoxic activities to pathogens [45]. In our study, one PPO protein was highly expressed in both cultivars as measured using 2-DE, especially in 'Zheza-301', in which it increased 15-fold in protein abundance ratio. By contrast, the expression pattern of $P P O$ gene measured using qRT-PCR exhibited a down-regulated expression profile both in 'Zheza-310' and 'Jinpeng-1'.

In addition to PPO, APX, a lactoylglutathione lyase protein (spot 83), known as glyoxalase I (Glo I) was induced after TYLCV infection in both tomato cultivars. This enzyme catalyzes the formation of S-D-lactoylglutathione from methylglyoxal and glutathione to reduce damage [48]. Methylglyoxal is a cytotoxic and mutagenic $\alpha$ ketoaldehyde that is significantly increased (2-6 fold) under abiotic stress in plants [49]. This compound can form adducts with proteins and nucleic acids, and damages cellular functions [49-52]. Glo I, encoding the Glo I protein, showed up-regulated transcription levels of about 3.0-fold and 2.5-fold in 'Zheza-301' and 'Jinpeng-1' at 19 dpi, respectively, while the protein abundance ratio was down-regulated in 'Zheza-301' (Fig. 9, Table 1). CHI is a kind of pathogenesis-related protein that can be dramatically induced by fungal, bacterial or viral attacks, and which can hydrolyze chitin in the fungal cell wall to protect the plant from biotic and abiotic stresses [52-54]. After TYLCV infection, the activity of $\mathrm{CHI}$ protein is increased more than in uninfected tomatoes sprayed with eugenol. In the study, $\mathrm{CHI}$ protein was induced in both 'Zheza-301' and 'Jinpeng-1'. The protein abundance ratio in 'Jinpeng1' was more than 4.2-fold that in 'Zheza-301'. Quantitative PCR showed significantly increased expression of the $\mathrm{CHI}$ gene in 'Zheza-301' and 'Jinpeng-1' from $10 \mathrm{dpi}$ and 12fold and 35-fold increases, respectively, at 19 dpi (Figs. 8 and 9). The similar expression patterns of $\mathrm{CHI}$ protein in the two cultivars indicates that $\mathrm{CHI}$ protein plays an important role in the resistance of plants to TYLCV.

\section{Chaperones}

Plant cells can be injured by protein misfolding or unfolding when they are confronted with adverse conditions $[55,56]$. Many studies have shown that heat shock proteins (HSPs) can refold proteins to maintain cellular homeostasis and reestablish normal protein conformation under adverse conditions [24]. HSC70s are a major family of chaperones that play essential roles in a range of protein-folding processes, including protein import and translocation, and that facilitate degradation of unstable proteins [57, 58]. Another study indicated that HSP83 proteins are involved in a general regulation mechanism and control a variety of cellular functions $[59,60]$. In avocados, a small $17.3 \mathrm{kDa}$ heat-shock protein is induced after infection with the oomycete Phytophthora cinnamomi [18]. HSP70 is overrepresented in inoculated cashew plants after Lasiodiplodia theobromae infection [19]. In this study, HSC70 and two isoforms of HSP83 were identified in both 'Zheza301 ' and 'Jinpeng-1' with up-regulated protein abundance ratios after TYLCV infection. HSP83 and HSC70 showed higher protein abundance ratios, which increased 9.5-fold and 9.2-fold, respectively, in'Jinpeng-1'. As shown in Fig. 9, the transcription levels of HSC7O were up-regulated in both tomato cultivars with 12 -fold (in 'Zheza-301') and 8-fold (in 'Jinpeng-1') higher expression. All these results indicate that HSPs play a crucial role in recognizing and correcting misfolded proteins under TYLCV infection in tomato.

\section{Signal transduction proteins}

14-3-3 proteins, as important regulators of cellular signal transduction and primary metabolism in plants, are ubiquitous in eukaryotes; these proteins regulate plant development and protect plants from adverse conditions $[61,62]$. Previous studies have shown that $14-3-3$ protein can respond to various abiotic stresses, such as environmental stress [63], metabolism/nutrient stress [64], herbivory and wound stress [65], and biotic stress, such as Magnaporthe grisea and Xanthomonas oryzae in rice [61]. Moreover, 14-3-3 protein may control the activities of kinases and phosphatases by taking part in various signal transduction processes [66]. After TYLCV infection, the protein abundance ratios of 14-3-3 protein in 'Zheza301 ' and 'Jinpeng-1' showed a significant decrease. This decrease indicates that 14-3-3 is down-regulated in response to TYLCV infection.

\section{Other important proteins involved in TYLCV infection}

Serine carboxypeptidases play important roles in plant growth and development, being involved in protein hydrolyzation, signal transduction and response to trauma and adverse conditions [67-71]. Two isoforms of CAR (spots 41, 42) were identified as having positive protein abundance ratios in the two tomato cultivars (Table 1). CDC48 was up-regulated in both 'Jinpeng-1' and 'Zheza301 ' as measured by both qRT-PCR and 2-DE (Fig. 9, Table 1). As shown in Fig. 9, the expression patterns of three genes (OEE1,CAB and LFNR), that encode photosynthesis-related proteins, and four energy genes (GAPDH, EA, AH and $I D$ ), related to carbon metabolism, were identified by qRT-PCR at $19 \mathrm{dpi}$. The transcription levels of $O E E 1, C A B, I D$ and $A H$ were higher both in 'Zheza-301' and 'Jinpeng-1'. LFNR and EA, encoding ferredoxin-NADP reductase and enolase, were down-regulated. GLDC, CYS, THD and MAT, which are involved in amino acid metabolism, showed different transcription profiles in the two tomato cultivars. THD 
increased 5- and 10-fold in 'Zheza-301' and 'Jinpeng-1', respectively. MAT was down-regulated in both tomato cultivars. The expression levels of ID were opposite in 2DE and qRT-PCR analyses, with 2-DE showing downregulation and qRT-PCR showing up-regulation (Fig. 9, Table 1). A complex process from the gene to the corresponding protein involves complicated translation and modification, which may cause the difference in expression levels observed between the gene and protein.

\section{TYLCV CP aggregation in different tomato cultivars}

The CP of TYLCV forms a capsid and exhibits various functions [72]. Gorovits et al. detected TYLCV CP with weak expression levels in susceptible '906-4' tomato plants at 14 dpi but not in resistant '902' tomato plants until 21 dpi [31]. In our study, TYLCV CP was not detected by 2-DE in the resistant cultivar 'Zheza-301' or the susceptible cultivar 'Jinpeng-1' at 19 dpi. A total of 500 protein spots with different protein abundances were identified using PDQuest software with an automation mode (data not shown). Only 86 protein spots with obviously different expression levels were manually selected, excised and analyzed through matrix-assisted laser desorption/ionization time-of-flight mass spectrometry (MALDI-TOF-TOF MS). The CP protein spot may not have been excised; consequently, the $\mathrm{CP}$ protein was not detected. The CP protein may be among the 414 spots that were not analyzed.

Viral replication, transcription, translation and movement, as well as virus inoculum dose and inoculation methods, influence the aggregation level of TYLCV CP in tomato plants [31]. Different tomato genotypes and resistance to TYLCV infection also affect TYLCV CP expression. After TYLCV infection, host compounds such as chaperones, proteases and stress-induced proteins also contribute to the maintenance of small aggregates in tomato plants [32]. Genetic backgrounds and resistance to TYLCV infection differ between 'Jinpeng-1' and '906-4'. Thus, these parameters influenced the accumulation of TYLCV CP [20, 29]. To analyze TYLCV CP

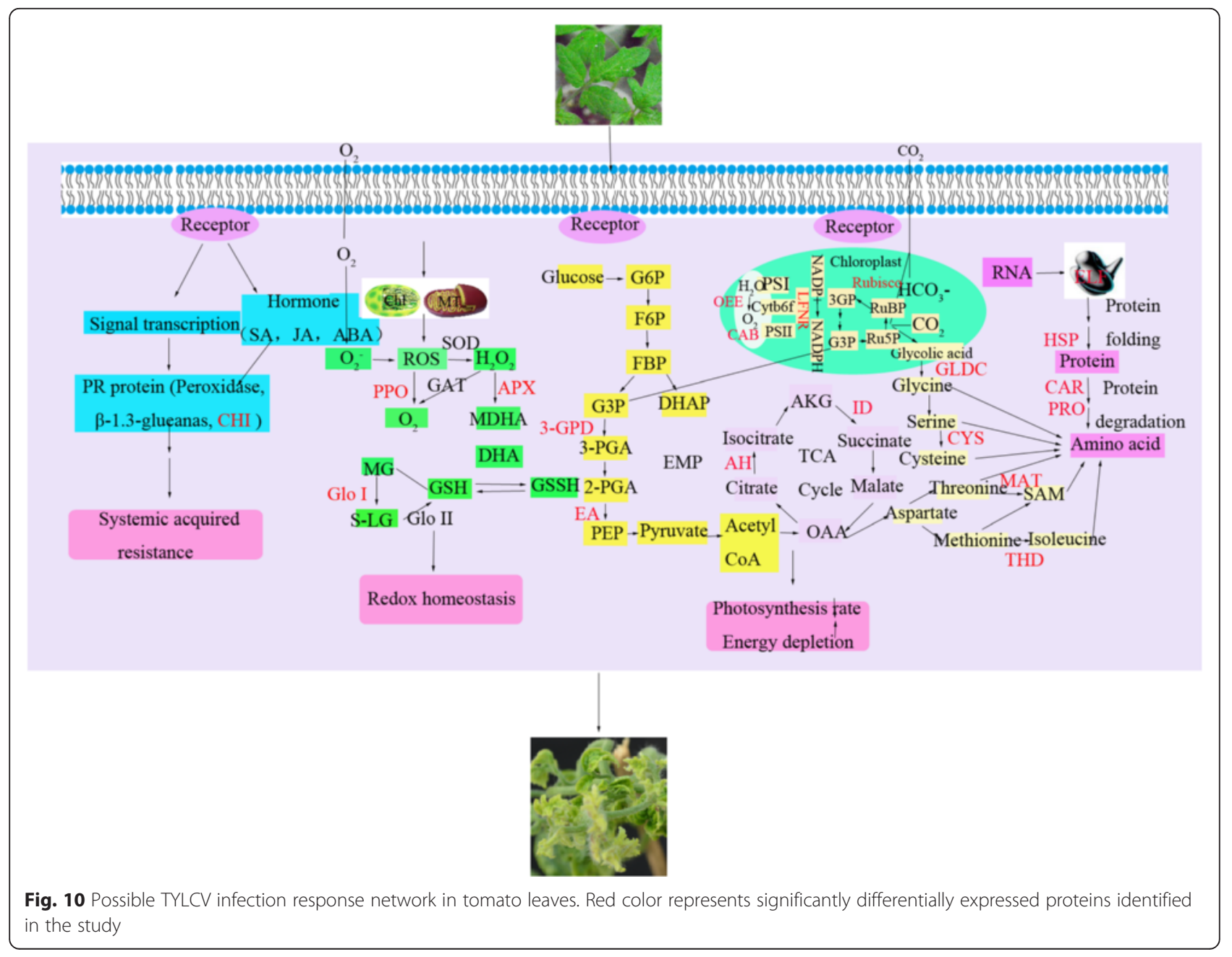


accumulation in tomato, we will extend the time of infection with TYLCV or use isobaric tags for relative and absolute quantification (iTRAQ) in further studies [73].

\section{A putative TYLCV infection response network in tomato leaves}

Based on proteomic analysis, 86 proteins were identified in tomato leaves at $19 \mathrm{dpi}$. A TYLCV infection response network was proposed that included the majority of the 86 TYLCV-responsive proteins, which are involved in several functional processes, such as systemic acquired resistance, redox homeostasis, photosynthesis rate, energy metabolism, proteolysis and amino acid hydrolysis.

As shown in Fig. 10, tomato leaves perceive a stress signal after TYLCV infection, through some receptors located on the membrane and transmit it to cellular mechanisms by signal transduction processes that alter many cellular and metabolic processes. The level of certain hormones such as salicylic acid (SA), jasmonicacid (JA), abscisic acid (ABA) and some pathogenesis-related (PR) proteins including $\mathrm{CHI}$ and $\beta$-1.3-glucanase were induced in response to TYLCV infection and confer systemic acquired resistance [32, 74]. The increase in ROS content after TYLCV infection could cause an imbalance of redox in tomato leaves. To maintain redox homeostasis, the synthesis of antioxidation enzymes such as SOD, APX, Glo I and PPO, increases to decrease the levels of ROS and allow the cell to achieve redox balance. The photosynthetic rate of tomato leaves is impaired by the downregulation of RuBisCO, LFNR and CAR protein (Table 1). Energy metabolism of tomatoes under TYLCV infection is increased by up-regulation of $I D$ and $A H$, which improves the ability of tomato leaves to respond to TYLCV infection and decrease the damage (Fig. 9). After TYLCV infection, protein biosynthesis of tomato leaves is inhibited through the down-regulation of EF-4A-2, whereas proteolysis increases because of up-regulation of PRO and CAR proteins. Amino acid metabolism of tomato leaves is enhanced by the over-expression of THD and GLDC proteins.

Through the changes of cellular signal transduction and metabolic processes, tomato leaves strive to resist TYLCV infection and adapt to or decrease the damage caused by TYLCV. In the current study, a putative interaction network between tomato leaves and TYLCV infection provides us with important information about the strategy of cellular activities responding to TYLCV infection in tomato leaves.

\section{Comparative analysis with other 'omics' used to study plant-virus interactions}

'Omics' technologies, including transcriptomics, proteomics and metabolomics can be applied to monitor and capture complete changes that occur under adverse conditions at transcript, protein and metabolic levels [75, 76]. In plants, geminivirus infections, including TYLCV, have rarely been subjected to transcriptomic analysis. A total of 3604 genes and 34,831 transcripts were identified through transcriptomics, as conducted by Miozzi et al. and Chen et al., respectively [16, 35]. Only 86 significantly differentially expressed proteins were identified in this study using proteomics. Changes in gene expression at the transcript level are not well correlated with alterations in protein levels because of transcript instability and post-transcriptional modification. Genes encoding different proteins involved in TYLCV infection were revealed through transcriptomic and proteomic analyses; these genes included HSP, CHI and CYS. Gene ontology analysis also demonstrated that genes identified through transcriptomic and proteomic analyses were mainly involved in response to biotic stress, amino acid metabolism and protein degradation. Regulatory factors, such as MYB, NAC and WRKY, could be identified through transcriptomics but not through proteomic analysis. These proteins are often difficult to investigate because of their low abundance [16, 35].

In the innate immune response of plants, small molecules can be analyzed in detail and compounds can be identified through metabolomic approaches [77]. The combination of global gene expression and metabolic profiling is a powerful approach that can provide comprehensive insights into cellular dynamics associated with pathogen infections [17, 33]. After TYLCV infection occurs, numerous metabolites are involved in several metabolic pathways, such as phenylpropanoids and lignins; these metabolites exhibit different regulatory mechanisms between resistant and susceptible tomato cultivars [17]. Glucosamine is a metabolic compound involved in ROS metabolism; the amounts of glucosamine decreased in the early stages of infection but sharply increased at 25-28 dpi [33]. The protein abundance ratio of APX (spot 81) involved in antioxidation was upregulated in the two tomato cultivars (Table 1). The findings indicate that changes in primary and secondary metabolites occur in the defense against TYLCV infection in tomato.

Proteomics has been used to investigate the potential functional mechanisms involved in resistance to pathogen infections in tomatoes [78, 79]. Proteins, including APX and OEE, have been identified in proteomics data from TYLCV-infected, TMV-infected, and cucumber mosaic virus (CMV)-infected tomato plants $[78,80]$. $\mathrm{CHI}$ and LAP have been identified in TYLCV-infected and TMV-infected tomato plants. After TYLCV and CMV infection occurs, photosynthesis, energy metabolism and carbon metabolism are altered in tomato plants. Proteins involved in defense responses are also induced. HSP, which functions as a chaperone, is induced at 4 weeks post-TYLCV infection and at $19 \mathrm{dpi}$ [33]. 


\section{Conclusions}

A comprehensive proteomics analysis in the leaves of resistant and susceptible tomato cultivars was conducted. Eighty-six protein spots were identified with more than 2 -fold or less than 0.5 -fold in protein abundance ratio after TYLCV infection in two cultivars. Classified into seven functional groups, proteins identified after TYLCV infection played different roles in the process of tomato-TYLCV interaction. The interaction network between tomato leaves and TYLCV infection provided us the information about the possible activities in tomato leaf cells. The results will help to find the key proteins involved in tomato-TYLCV interaction to enhance the resistance to TYLCV and obtain protection from virus infection.

\section{Methods}

\section{Plant materials and TYLCV infection}

In this study, resistant tomato cultivar 'Zheza-301', derived from T5678161-1-1-2-2 and T07-018, and susceptible tomato cultivar 'Jinpeng-1', a hybrid of Holland tomato cultivar 99-13A and 9708B from America, were chosen as the source for the comparative proteomic analysis. 'Zheza301 ' was identified as carrying the Ty-2 locus, which because T07-018 was selected from the 4th generation of the 'CLN2498E', breeding to contain the Ty-2 resistant gene [81]. Seeds of tomato cultivars 'Zheza-301' and 'Jinpeng-1' were obtained from the Institute of Vegetables, Zhejiang Academy of Agricultural Sciences, and Xi'an Jinpeng Seed Co., Ltd., respectively. Tomato plantlets of 'Zheza-301' and 'Jinpeng-1' were grown in a chamber under $25^{\circ} \mathrm{C} / 18^{\circ}$ $\mathrm{C}, 12 \mathrm{~h} /$ day and a relative humidity of 60-70 \% [29]. Viruliferous whiteflies, provided by Provincial Key Laboratory of Agrobiology, Jiangsu Academy of Agricultural Sciences (Nanjing, China), were allowed to feed on tomato plants in an insect-proof greenhouse. Tomato plantlets at the two-leaf stage were transmitted to the insect-proof greenhouse to expose them to viruliferous whiteflies. Control plants were transmitted to an insect-proof greenhouse without viruliferous whiteflies. The leaves of TYLCVinfected tomato plants were harvested at 2, 4, 6, 10, 15 and $19 \mathrm{dpi}$. To guarantee a better comparative understanding of the development of infection between resistant and susceptible tomato cultivars, leaves of the two tomato cultivars were processed at $19 \mathrm{dpi}$; at this point, systemic symptoms, including curly yellow leaves, were apparent in 'Jinpeng-1' but not in 'Zheza-301'. The leaves of control and infected tomato cultivars at 19 dpi were collected and frozen for protein extraction.

\section{Protein extraction and 2-DE}

Three biological repeats of each sample were collected to improve accuracy. According to the Bio-Rad (Hercules, CA, USA) 2-D manual, acetone/trichloroacetic acid (TCA) precipitation method was used to extract protein with slight modifications. Tomato leaf sample powder was briefly suspended in $10 \% \mathrm{w} / \mathrm{v}$ TCA/acetone containing $1 \mathrm{mM}$ phenylmethanesulfonyl fluoride (PMSF) and $0.07 \% \mathrm{w} / \mathrm{v} \beta$-mercaptoethanol, and held at $-20{ }^{\circ} \mathrm{C}$ for $1 \mathrm{~h}$. Approximately $800 \mu \mathrm{L}$ of lysis solution (containing $7 \mathrm{M}$ urea, $2 \mathrm{M}$ thiourea, $4 \%$ (w/v) 3-[(3-cholamidopropyl) dimethylammonium]-1-propanesulfonate, $65 \mathrm{mM}$ dithiothreitol, $1 \mathrm{mM}$ PMSF and $0.5 \% \mathrm{v} / \mathrm{v}$ biolytes) was used to dissolve the vacuum-dried pellets after centrifugation and rinse. After centrifugation, the insoluble materials were removed. The Bradford method was performed to quantify the protein concentration for each sample [82]. About $1500 \mu \mathrm{g}$ of protein of each sample was loaded on a $24 \mathrm{~cm}$ nonlinear gradient immobilized $\mathrm{pH}$ gradient strip (pH 4-7) and subjected to IEF at $20^{\circ} \mathrm{C}: 50 \mathrm{v}$ for $13 \mathrm{~h}, 100 \mathrm{v}$ for $1 \mathrm{~h}, 200 \mathrm{v}$ for $1 \mathrm{~h}, 1000 \mathrm{v}$ for $1 \mathrm{~h}, 8000 \mathrm{v}$ for $3 \mathrm{~h}$, and $8000 \mathrm{v}$ for a total of $110,000 \mathrm{VH}$. Afterward, $12 \%$ sodium dodecyl sulfate polyacrylamide gel electrophoresis (SDSPAGE) was used for the second electrophretic dimension. Proteins were observed by staining with Coomassie Brilliant Blue G-250. A gel scanner (Powerlook 2100XL, UMAX) and PDQuest software package (ver 7.2.0; Bio-Rad), with automation mode, were used to digitalize and analyze the gel images, respectively [83]. Based on the total density of gels with the parameter of percentage volume, spots were detected, matched and normalized. Subsequently, the mean relative volume of each spot by three biological repeats was computed and spots with more than 2.0-fold and less than 0.5 -fold of protein abundance ration was considered differentially expressed protein. The experimental design was showed in Additional file 4: Figure S3.

\section{In-gel digestion and MALDI-TOF-TOF MS analysis}

Differentially expressed protein spots were manually excised, washed three times with Millipore pure water and destained twice with $50 \mathrm{mM} \mathrm{NH}_{4} \mathrm{HCO}_{3}$ in $50 \%$ acetonitrile (ACN). Afterward, $10 \mathrm{mM}$ dithiothreitol in $50 \mathrm{mM}$ $\mathrm{NH}_{4} \mathrm{HCO}_{3}$ was used to reduce alkylation with $40 \mathrm{mM}$ iodoacetamide in $50 \mathrm{mM} \mathrm{NH} \mathrm{HCO}_{3}$. $\mathrm{ACN}$ (100\%) was employed to dry twice and was digested overnight at $37^{\circ} \mathrm{C}$ with sequencing grade modified trypsin (Promega, Madison, WI, USA) in $50 \mathrm{mM} \mathrm{NH} \mathrm{HCO}_{3}$. The peptides were extracted twice with $0.1 \%$ trifluoroacetic acid (TFA) in $50 \% \mathrm{ACN}$. After being pooled and lyophilized, the resulting lyophilized tryptic peptides were dissolved in $5 \mathrm{mg} / \mathrm{mL}$ CHCA containing $0.1 \%$ TFA and $50 \%$ acetonitrile. A 4800 plus MALDI-TOF-TOF TM analyzer (Applied Biosystems, Foster City, CA, USA) was used for analyses.

MASCOT program online was employed to search the database of all protein spectra (http://www.matrixscience. com), against NCBInr databases. The search parameters were as follows: $0.15 \mathrm{Da}$ mass tolerance for peptides and $0.25 \mathrm{Da}$ mass tolerance of TOF-TOF fragments, 
one allowed trypsin miscleavage, carbamidomethyl of cystine (Cys) as fixed modification, oxidation of methionine (Met), and pyro-glutamicacid (Glu) formation of N-terminal glutarnine (Gln) and Glu as variable modification. To select the significant hits, the protein abundance ratio of each spot (treatment/control) with more than 2.0-fold or less than 0.5 -fold was formulated as the selection criteria. Only significant hits, which were identified by the MASCOT probability analysis, were accepted.

\section{Bioinformatic analysis}

The protein abundance ratio of each spot shown in Table 1 was analyzed and normalized using a $\log 2$ transform, and then a heat map with hierarchical clustering was produced using HemI 1.0 software [84].

\section{Semi-quantitative PCR and qRT-PCR analysis}

The total RNA of tomato leaves was extracted using an RNA kit (RNA simple total RNA kit, Tiangen, Beijing, China) and then transcribed into cDNA using a Primer Script RT reagent kit (TaKaRa, Dalian, China), respectively. qRT-PCR with SYBR Premix Ex Taq was conducted using an ABI7500 (Applied Biosystems, Foster, CA, USA) according to the following procedure: $95^{\circ} \mathrm{C}$ for $30 \mathrm{~s}$, followed by 40 cycles at $95{ }^{\circ} \mathrm{C}$ for $5 \mathrm{~s}$ and $60{ }^{\circ} \mathrm{C}$ for $30 \mathrm{~s}$, and melting curve analysis (61 cycles) at $65{ }^{\circ} \mathrm{C}$ for $10 \mathrm{~s}$. Primer Premier 5.0 software was used to design the primer of each selected protein and A-Tubulin (Solyc04g077020.2) was used to regulate the expression level [85]. The expression patterns of two genes ( $T y-1$ and Ty-5) associated with the Ty locus were assessed after TYLCV infection in the two tomato cultivars, $18 \mathrm{~S}$ ribosomal RNA was used as reference with the following primers 5'-GCGACGCATCATTCAAATTTC-3' and 5' -TCCGGA ATCGAACCCTAATTC-3' [22].

To detect whether there was accumulation of TYLCV DNA after TYLCV infection, semi-quantitative PCR was conducted using the primers TYLCV-01 F/R. A-Tubulin was used as internal control for semi-quantitative PCR and qRT-PCR. Total DNA was extracted from leaves of two tomato cultivars (control and treatment) using a DNA kit (DNAsecure Plant Kit, Tiangen, Beijing, China). The condition and parameters of PCR were $95{ }^{\circ} \mathrm{C}$ for $5 \mathrm{~m}$, followed by different cycles $(23,25,27$ and 30$)$ at $95{ }^{\circ} \mathrm{C}$ for $30 \mathrm{~s}, 54{ }^{\circ} \mathrm{C}$ for $1 \mathrm{~m}, 72{ }^{\circ} \mathrm{C} 1 \mathrm{~m}$, then $72{ }^{\circ} \mathrm{C} 10 \mathrm{~m}$. Primers used in the study were shown in Additional file 2: Table S1.

\section{Additional files}

Additional file 1: Figure S1. Symptoms of two tomato cultivars after TYLCV infection at different time. (TIF $4475 \mathrm{~kb}$ )
Additional file 2: Table S1. Primers of the selected genes used in the text. (DOC $58 \mathrm{~kb})$

Additional file 3: Figure S2. Representative protein spot maps of leaves of tomato cultivars 'Zheza-301' (A) and 'Jinpeng-1' (B). CK stands for the control plants that tomato seedlings are grown in normal environment without TYLCV infection. Treatment means that tomato seeding is grown in normal environment with TYLCV infection. 2-DE was performed using $1500 \mathrm{~g}$ of protein, nonlinear $24 \mathrm{~cm}$ IPG strips (pH 4-7) and $12 \%$ SDS-PAGE gels for second dimension electrophoresis. (TIF $3424 \mathrm{~kb}$ )

Additional file 4: Figure S3. Experimental design of our research. (TIF $1401 \mathrm{~kb}$ )

\section{Abbreviations}

2-DE, two-dimensional gel electrophoresis; ABA, abscisic acid; AD, aryl-al/cohol dehydrogenase related protein; $\mathrm{AH}$, aconitate hydratase; APX, ascorbate peroxidase; $C A B$, chlorophyll a-b binding protein 4 ; CAR, wound-inducible carboxypeptidase precursor; $C D C 48$, cell division cycle protein 48 homolog; $C H$, chitinase; CMV, cucumber mosaic virus; CP, coat protein; CYS, cysteine synthase; dpi, day post infection; EA, enolase; GAPDH, glyceraldehyde-3-phosphate dehydrogenase; GLDC, glycine dehydrogenase (decarboxylating); Glo I, lactoylglutathione lyase; Glu, glutamicacid; ID, isocitrate dehydrogenase; iTRAQ, isobaric tags for relative and absolute quantification; JA, jasmonicacid; KEGG, kyoto encyclopedia of genes and genomes; LAP, leucine aminopeptidase; LFNR, ferredoxin-NADP reductase, leaf-type isozyme; MALDI-TOF-TOF MS, matrixassisted laser desorption/ionization time-of-flight mass spectrometry; MAT, Sadenosylmethionine synthase 2; MG, methylglyoxal; MP, movement proteins; OEE, oxygen-evolving enhancer protein; ORF, open reading frame; $p l$, isoelectric point; PMSF, phenylmethanesulfonyl fluoride; PPO, polyphenol oxidase;

PR, pathogenesis-related proteins; PRO, subtilisin-like protease precursor; qRT$P C R$, quantitative real-time polymerase chain reaction; ROS, reactive oxygen species; SA, salicylic acid; ssDNA, single-stranded DNA; TCA, trichloroacetic acid; THD, threonine deaminase; TMV, tobacco mosaic virus; TYLCV, tomato yellow leaf curly virus

\section{Funding}

The research was supported by Jiangsu Natural Science Foundation (BK20130027), New Century Excellent Talents in University (NCET-11-0670), Priority Academic Program Development of Jiangsu Higher Education Institutions Project (PAPD).

\section{Availability of data and materials}

The data sets supporting the conclusions of this article are included within the article and its additional files.

\section{Authors' contributions}

ASX and YH conceived and designed the experiments, YH, HYM, WH, ZSX and FW performed the experiments, YH, HYM and ASX analyzed the data, YH wrote the paper. ASX and YH revised the paper. All authors read and approved the final manuscript.

\section{Competing interests}

The authors declare that they have no competing interests.

\section{Consent to publish}

Not applicable.

\section{Ethics approval and consent to participate}

Not applicable.

\section{Author details}

${ }^{1}$ State Key Laboratory of Crop Genetics and Germplasm Enhancement, College of Horticulture, Nanjing Agricultural University, 1 Weigang, Nanjing 210095, Jiangsu, China. ${ }^{2}$ College of Plant Protection, Nanjing Agricultural University, Nanjing 210095, Jiangsu, China.

Received: 6 January 2016 Accepted: 24 May 2016 Published online: 19 July 2016 


\section{References}

1. Regenmortel MHV, Mayo MA, Fauquet CM, Maniloff J. Virus nomenclature: consensus versus chaos. Arch Virol. 2000;145:2227-32.

2. Gafni Y, Epel BL. The role of host and viral proteins in intra- and inter-cellular trafficking of geminiviruses. Physiol Mol Plant Pathol. 2002;60:231-41.

3. Fuentes A, Ramos PL, Fiallo E, Callard D, Sanchez Y, Peral R, et al. Intronhairpin RNA derived from replication associated protein $\mathrm{C} 1$ gene confers immunity to tomato yellow leaf curl virus infection in transgenic tomato plants. Transgenic Res. 2006;15:291-304.

4. Ge L, Zhang J, Zhou X, Li H. Genetic structure and population variability of tomato yellow leaf curl China virus. J Virol. 2007;81:5902-7.

5. Latham JR, Keith S, Pinner MS, John S. Induction of plant cell division by beet curly top virus gene C4. Plant J. 1997;11:1273-83.

6. Moriones E, Navas-Castillo J. Tomato yellow leaf curl virus, an emerging virus complex causing epidemics worldwide. Virus Res. 2000;71:123-34.

7. Zhang J, Dong J, Xu Y, Wu J. V2 protein encoded by tomato yellow leaf curl China virus is an RNA silencing suppressor. Virus Res. 2012;163:51-8.

8. Zrachya A, Kumar PP, Ramakrishnan U, Levy Y, Loyter A, Arazi T, et al. Production of siRNA targeted against TYLCV coat protein transcripts leads to silencing of its expression and resistance to the virus. Transgenic Res. 2007;16:385-98.

9. Morilla G, Janssen D, García-Andrés S, Moriones E, Cuadrado IM, Bejarano ER. Pepper (Capsicum annuum) is a dead-end host for tomato yellow leaf curl virus. Phytopathology. 2007;95:305-25.

10. Zhou XP, Xie $Y$, Zhang ZK. Molecular characterization of a distinct begomovirus infecting tobacco in Yunnan, China. Arch Virol. 2001;146:1599-606.

11. Jones DR. Plant viruses transmitted by whiteflies. Eur J Plant Pathol. 2003; 109:195-219.

12. Akad F, Eybishtz A, Edelbaum D, Gorovits R, Dar-Issa O, Iraki N, et al. Making a friend from a foe: expressing a GroEL gene from the whitefly Bemisia tabaci in the phloem of tomato plants confers resistance to tomato yellow leaf curl virus. Arch Virol. 2007;152:1323-39.

13. Sade D, Eybishtz A, Gorovits R, Sobol I, Czosnek H. A developmentally regulated lipocalin-like gene is overexpressed in tomato yellow leaf curl virus-resistant tomato plants upon virus inoculation, and its silencing abolishes resistance. Plant Mol Biol. 2012;80:273-87.

14. Wang J, Hu Z, Zhao T, Yang Y, Chen T, Yang L, et al. Genome-wide analysis of bHLH transcription factor and involvement in the infection by yellow leaf curl virus in tomato (Solanum lycopersicum). BMC Genomics. 2015;16:1-14.

15. Huang $Y$, Zhang $B$, Sun S, Xing G, Wang F, Li M, et al. AP2/ERF transcription factors involved in response to tomato yellow leaf curly virus in tomato. Plant Genome. 2016;9:1-15.

16. Chen T, Lv Y, Zhao T, Li N, Yang Y, Yu W, et al. Comparative transcriptome profiling of a resistant vs susceptible tomato (Solanum lycopersicum) cultivar in response to infection by tomato yellow leaf curl virus. PLoS One. 2013;8:e80816.

17. Sade D, Shriki O, Cuadros-Inostroza A, Tohge T, Semel Y, Haviv Y, et al. Comparative metabolomics and transcriptomics of plant response to tomato yellow leaf curl virus infection in resistant and susceptible tomato cultivars. Metabolomics. 2015;11:81-97.

18. Acosta-Muniz CH, Escobar-Tovar L, Valdes-Rodriguez S, Fernandez-Pavia S, Arias-Saucedo $L$, de la Cruz Espindola Barquera M, et al. Identification of avocado (Persea americana) root proteins induced by infection with the oomycete Phytophthora cinnamomi using a proteomic approach. Physiol Plant. 2012;144:59-72.

19. Cipriano AK, Gondim DM, Vasconcelos IM, Martins JA, Moura AA, Moreno FB, et al. Proteomic analysis of responsive stem proteins of resistant and susceptible cashew plants after Lasiodiplodia theobromae infection. J Proteomics. 2015;113:90-109.

20. Vidavsky F, Czosnek $\mathrm{H}$. Tomato breeding lines resistant and tolerant to tomato yellow leaf curl virus issued from Lycopersicon hirsutum. Phytopathology. 1998:88:910-4.

21. Verlaan MG, Hutton SF, Ibrahem RM, Kormelink R, Visser RG, Scott JW, et al. The tomato yellow leaf curl virus resistance genes $T y-1$ and $T y$-3 are allelic and code for DFDGD-class RNA-dependent RNA polymerases. PLoS Genet. 2013;9:e1003399.

22. Lapidot M, Karniel U, Gelbart D, Fogel D, Evenor D, Kutsher Y, et al. A novel route controlling begomovirus resistance by the messenger RNA surveillance factor pelota. PLoS Genet. 2015;11:e1005538.

23. Wan XY, Liu JY. Comparative proteomics analysis reveals an intimate protein network provoked by hydrogen peroxide stress in rice seedling leaves. Mol Cell Proteomics. 2008;7:1469-88.
24. Wang L, Liu X, Liang M, Tan F, Liang W, Chen Y, et al. Proteomic analysis of salt-responsive proteins in the leaves of mangrove Kandelia candel during short-term stress. PLoS One. 2014;9:e83141.

25. Mayfield SP, Bennoun P, Rochaix JD. Expression of the nuclear encoded oee 1 protein is required for oxygen evolution and stability of photosystemii particles in Chlamydomonas Reinhardtii. EMBO J. 1987;6:313-8.

26. Sugihara K, Hanagata N, Dubinsky Z, Baba S, Karube I. Molecular characterization of cDNA encoding oxygen evolving enhancer protein 1 increased by salt treatment in the mangrove Bruguiera gymnorrhiza. Plant Cell Physiol. 2000;41:1279-85.

27. Tiwari A, Kumar P, Singh S, Ansari SA. Carbonic anhydrase in relation to higher plants. Photosynthetica. 2005;43:1-11.

28. Zadraznik T, Hollung K, Egge-Jacobsen W, Meglic V, Sustar-Vozlic J. Differential proteomic analysis of drought stress response in leaves of common bean (Phaseolus vulgaris L.). J Proteomics. 2013;78:254-72.

29. Tian Z, Liu W, Xie H, Xing R, Chai M, Luo C. Resistance identification of tomato varieties against tomato yellow leaf curl virus. Acta Phytophy Sin. 2013;40:56-60.

30. Khalil RR, Bassiouny FM, El-Dougdoug KA, Abo-Elmaty S, Yousef MS. A dramatic physiological and anatomical changes of tomato plants infecting with tomato yellow leaf curl germinivirus. Inter J Agr Sustain. 2014;10:1213-29.

31. Gorovits R, Moshe A, Kolot M, Sobol I, Czosnek H. Progressive aggregation of tomato yellow leaf curl virus coat protein in systemically infected tomato plants, susceptible and resistant to the virus. Virus Res. 2013;171:33-43.

32. Gorovits R, Akad F, Beery H, Vidavsky F, Mahadav A, Czosnek H. Expression of stress-response proteins upon whitefly-mediated inoculation of tomato yellow leaf curl virus in susceptible and resistant tomato plants. Mol Plant Microbe Interact. 2007;20:1376-83.

33. Adi M, Jens P, Brotman Y, Mikhail K, Iris S, Henryk C, et al. Stress responses to tomato yellow leaf curl virus (TYLCV) infection of resistant and susceptible tomato plants are different. Metabolomics. 2012;51:006.

34. Glick E, Levy Y, Gafni Y. The viral etiology of tomato yellow leaf curl disease - A review. Plant Protect Sci. 2009:45:81-97.

35. Miozzi L, Napoli C, Sardo L, Accotto GP. Transcriptomics of the interaction between the monopartite phloem-limited geminivirus tomato yellow leaf curl sardinia virus and Solanum lycopersicum highlights a role for plant hormones, autophagy and plant immune system fine tuning during infection. PLoS One. 2014;9:e89951.

36. Sade D, Brotman $Y$, Eybishtz A, Cuadros-Inostroza A, Fernie AR, Willmitzer $L$, et al. Involvement of the hexose transporter gene LeHT1 and of sugars in resistance of tomato to tomato yellow leaf curl virus. Mol Plant. 2013;6:1707-10.

37. Corbineau F, Gay-Mathieu C, Vinel D, Come D. Decrease in sunflower (Helianthus annuus) seed viability caused by high temperature as related to energy metabolism, membrane damage and lipid composition. Physiol Plant. 2002;116:489-96.

38. Lopez-Gresa MP, Maltese F, Belles JM, Conejero V, Kim HK, Choi YH, et al. Metabolic response of tomato leaves upon different plant-pathogen interactions. Phytochem Anal. 2010;21:89-94.

39. Diaz-Vivancos P, Rubio M, Mesonero V, Periago PM, Barcelo AR, MartinezGomez P, et al. The apoplastic antioxidant system in prunus: response to long-term plum pox virus infection. J Exp Bot. 2006;57:3813-24.

40. Hernandez JA, Rubio M, Olmos E, Ros-Barcelo A, Martinez-Gomez P. Oxidative stress induced by long-term plum pox virus infection in peach (Prunus persica). Physiol Plant. 2004;122:486-95.

41. Song XS, Wang YJ, Mao WH, Shi K, Zhou YH, Nogues S, et al. Effects of cucumber mosaic virus infection on electron transport and antioxidant system in chloroplasts and mitochondria of cucumber and tomato leaves. Physiol Plant. 2009;135:246-57.

42. Diaz-Vivancos P, Clemente-Moreno MJ, Rubio M, Olmos E, Garcia JA, Martinez-Gomez P, et al. Alteration in the chloroplastic metabolism leads to ROS accumulation in pea plants in response to plum pox virus. J Exp Bot. 2008:59:2147-60.

43. Riedle-Bauer M. Role of reactive oxygen species and antioxidant enzymes in systemic virus infections of plants. J Phytopathol. 2000;148:297-302.

44. Zhou YH, Yu JQ, Mao WH, Huang LF, Song XS, Nogues S. Genotypic variation of rubisco expression, photosynthetic electron flow and antioxidant metabolism in the chloroplasts of chill-exposed cucumber plants. Plant Cell Physiol. 2006;47:192-9.

45. Li L, Steffens JC. Overexpression of polyphenol oxidase in transgenic tomato plants results in enhanced bacterial disease resistance. Planta. 2002;215:239-47.

46. Mayer AM. Polyphenol oxidases in plants - recent progress. Phytochemistry. 1987;26:11-20. 
47. Soylu S. Accumulation of cell-wall bound phenolic compounds and phytoalexin in Arabidopsis thaliana leaves following inoculation with pathovars of Pseudomonas syringae. Plant Sci. 2006;170:942-52.

48. Espartero J, Sanchez-Aguayo I, Pardo JM. Molecular characterization of glyoxalase-I from a higher plant; upregulation by stress. Plant Mol Biol. 1995; 29:1223-33.

49. Yadav SK, Singla-Pareek SL, Ray M, Reddy MK, Sopory SK. Methylglyoxal levels in plants under salinity stress are dependent on glyoxalase I and glutathione. Biochem Biophys Res Commun. 2005;337:61-7.

50. Li Y, Cohenford MA, Dutta U, Dain JA. The structural modification of DNA nucleosides by nonenzymatic glycation: an in vitro study based on the reactions of glyoxal and methylglyoxal with 2 '-deoxyguanosine. Anal Bioanal Chem. 2008;390:679-88.

51. Speer O, Morkunaite-Haimi S, Liobikas J, Franck M, Hensbo L, Linder MD, et al. Rapid suppression of mitochondrial permeability transition by methylglyoxal role of reversible arginine modification. J Biol Chem. 2003;278:34757-63.

52. Wu CT, Bradford KJ. Class I chitinase and beta-1, 3-glucanase are differentially regulated by wounding, methyl jasmonate, ethylene, and gibberellin in tomato seeds and leaves. Plant Physiol. 2003;133:263-73.

53. Loon LCV. Induced resistance in plants and the role of pathogenesis-related proteins. Eur J Plant Pathol. 1997;103:753-65.

54. Sindelarova $M$, Sindelar $L$. Changes in composition of soluble intercellular proteins isolated from healthy and TMV-infected Nicotiana tabacum L. CV. Xanthi-nc. Biol Plantarum. 2001;44:567-72.

55. Kosova K, Vitamvas P, Prasil IT, Renaut J. Plant proteome changes under abiotic stress-contribution of proteomics studies to understanding plant stress response. J Proteomics. 2011;74:1301-22.

56. Hsieh TY, Nillegoda NB, Tyedmers J, Bukau B, Mogk A, Kramer G. Monitoring protein misfolding by site-specific labeling of proteins in vivo. PLoS One. 2014;9:e99395

57. Hartl FU. Molecular chaperones in cellular protein folding. Nature. 1996; 381:571-80

58. Wang W, Vinocur B, Shoseyov O, Altman A. Role of plant heat-shock proteins and molecular chaperones in the abiotic stress response. Trends Plant Sci. 2004;9:244-52.

59. Conner TW, Lafayette PR, Nagao RT, Key JL. Sequence and expression of a hsp83 from Arabidopsis thaliana. Plant Physiol. 1990;94:1689-95.

60. Lindquist S, Craig EA. The heat-shock proteins. Annu Rev Genet. 1988;22: 631-77.

61. Chen F, Li Q, Sun L, He Z. The rice 14-3-3 gene family and its involvement in responses to biotic and abiotic stress. DNA Res. 2006;13:53-63.

62. Li X, Dhaubhadel S. Soybean 14-3-3 gene family: identification and molecular characterization. Planta. 2011;233:569-82.

63. Babakov AV, Chelysheva W, Klychnikov OI, Zorinyanz SE, Trofimova MS, De Boer AH. Involvement of 14-3-3 proteins in the osmotic regulation of $\mathrm{H}$ +-ATPase in plant plasma membranes. Planta. 2000;211:446-8.

64. Cotelle V, Meek SE, Provan F, Milne FC, Morrice N, MacKintosh C. 14-3-3s regulate global cleavage of their diverse binding partners in sugar-starved Arabidopsis cells. EMBO J. 2000;19:2869-76.

65. Lapointe G, Luckevich MD, Cloutier M, Seguin A. 14-3-3 gene family in hybrid poplar and its involvement in tree defence against pathogens. J Exp Bot. 2001;52:1331-8.

66. Camoni L, Harper JF, Palmgren MG. 14-3-3 proteins activate a plant calciumdependent protein kinase (CDPK). FEBS Lett. 1998;430:381-4.

67. Dal Degan F, Rocher A, Cameron-Mills $V$, von Wettstein D. The expression of serine carboxypeptidases during maturation and germination of the barleygrain. Proc Natl Acad Sci U S A. 1994;91:8209-13.

68. Granat SJ, Wilson KA, Tan-Wilson AL. New serine carboxypeptidase in mung bean seedling cotyledons. J Plant Physiol. 2003;160:1263-6.

69. Li J, Lease KA, Tax FE, Walker JC. BRS1, a serine carboxypeptidase, regulates BRI1 signaling in Arabidopsis thaliana. Proc Natl Acad Sci U S A. 2001;98:5916-21.

70. Milkowski C, Strack D. Serine carboxypeptidase-like acyltransferases. Phytochemistry. 2004;65:517-24.

71. Moura DS, Bergey DR, Ryan CA. Characterization and localization of a wound-inducible type I serine-carboxypeptidase from leaves of tomato plants (Lycopersicon esculentum Mill.). Planta. 2001;212:222-30.

72. Czosnek H. Tomato yellow leaf curl virus. Encyclopedia Virol. 2008:5:138-45.

73. Robbins ML, Roy A, Wang PH, Gaffoor I, Sekhon RS, de O Buanafina MM, et al. Comparative proteomics analysis by DIGE and iTRAQ provides insight into the regulation of phenylpropanoids in maize. J Proteomics. 2013;93:254-75.
74. Sade D, Sade N, Shriki O, Lerner S, Gebremedhin A, Karavani A, et al. Water balance, hormone homeostasis, and sugar signaling are all involved in tomato resistance to tomato yellow leaf curl virus. Plant Physiol. 2014;165:1684-97.

75. Dinakar C, Bartels D. Desiccation tolerance in resurrection plants: new insights from transcriptome, proteome, and metabolome analysis. Front Plant Sci. 2013:4:3187-204.

76. Zhuang J, Zhang J, Hou XL, Wang F, Xiong AS. Transcriptomic, proteomic, metabolomic and functional genomic approaches for the study of abiotic stress in vegetable crops. Crit Rev Plant Sci. 2014;33:225-37.

77. Neumann S, Bocker S. Computational mass spectrometry for metabolomics: identification of metabolites and small molecules. Anal Bioanal Chem. 2010; 398:2779-88.

78. Di Carli M, Villani ME, Bianco L, Lombardi R, Perrotta G, Benvenuto E, et al. Proteomic analysis of the plant-virus interaction in cucumber mosaic virus (CMV) resistant transgenic tomato. J Proteome Res. 2010:9:5684-97.

79. Bocsanczy A, Achenbach UC, Norman DJ. Proteomics analysis of Ralstonia solanacearum identifies candidate proteins that contribute to pathogenicity on tomato plants at low temperatures. Phytopathology. 2010;100:S15-5.

80. Casado-Vela J, Selles S, Martinez RB. Proteomic analysis of tobacco mosaic virus-infected tomato (Lycopersicon esculentum M.) fruits and detection of viral coat protein. Proteomics. 2006;6:S196-206.

81. Hanson PM, Green SK, Kuo G. Ty-2, a gene on chromosome 11 conditioning geminivirus resistance in tomato. Tomato Genet Coop Rep. 2006;56:17-8.

82. $\mathrm{Ma} \mathrm{H}$, Song L, Shu Y, Wang S, Niu J, Wang ZK, et al. Comparative proteomic analysis of seedling leaves of different salt tolerant soybean genotypes. J Proteomics. 2012:75:1529-46.

83. Wheelock A, Buckpitt AR. Software-induced variance in two-dimensional gel electrophoresis image analysis. Electrophoresis. 2005;26:4508-20.

84. Deng W, Wang Y, Liu Z, Cheng H, Xue Y. Heml: A toolkit for illustrating heatmaps. PLoS One. 2014:9:e111988.

85. Lalitha S. Primer Premier 5. Biotech Softw Internet Rep. 2004;1:270-2.

\section{Submit your next manuscript to BioMed Central and we will help you at every step:}

- We accept pre-submission inquiries

- Our selector tool helps you to find the most relevant journal

- We provide round the clock customer support

- Convenient online submission

- Thorough peer review

- Inclusion in PubMed and all major indexing services

- Maximum visibility for your research

Submit your manuscript at www.biomedcentral.com/submit 